\section{Ecological Modelling}

Vol. 197, Issues 3-4 , 25 August 2006, P. 461-477

http://dx.doi.org/10.1016/i.ecolmodel.2006.03.016

(c) 2006 Elsevier B.V. All rights reserved
Archimer, archive institutionnelle de l'Ifremer http://www.ifremer.fr/docelec/

\title{
Comparative analysis of trophic structure and interactions of two tropical lagoons
}

\author{
M.C. Villanueva ${ }^{a, c, *}$, P. Lalèyè ${ }^{b}$, J.-J. Albaret ${ }^{c}$, R. Laë ${ }^{d}$, L. Tito de Morais ${ }^{e}$ and J. Moreau ${ }^{a}$
}

\begin{abstract}
aLaboratoire d'Agronomie, Environnement et Éco-toxicologie, Institut National Polytechnique de Toulouse (INPT), B.P. 32607 F, 31326 Castanet Tolosan, Cedex, France

${ }^{\mathrm{b}}$ Fac. des Sci. Agr. de l'Université d'Abomey Calavi-Bénin, B.P. 526 Cotonou, Bénin

${ }^{\mathrm{c}}$ Institut de Recherche pour le Développement (IRD), B.P. 1386, Dakar, Sénégal

${ }^{\mathrm{d}}$ Centre de Recherche Halieutique IFREMER/IRD, Brest Cedex, France

${ }^{\mathrm{e}}$ Centre de Recherche Halieutique IFREMER/IRD, Avenue Jean Monnet, B.P. 171 34203, Sète

Cedex, France
\end{abstract}

*: Corresponding author : Ching.Villanueva@ifremer.fr

\begin{abstract}
A comparative study of the Ébrié lagoon (Ivory Coast) and Lake Nokoué (Benin) was made based on ecotrophic model outputs that describe each system's structure and functioning. Two models were constructed using the Ecopath software to differentiate main biomass flows in the systems.

Results indicate that biomasses and productions in both ecosystems are concentrated in trophic levels (TL) 2 and 3. Higher TL biomasses and productions in Lake Nokoué compared to Ébrié lagoon may be explained by the presence of acadjas. High production per biomass $(P / B)$ and food consumption per biomass $(Q / B)$ values indicate the high productivity of these systems and the abundance of juveniles in most groups which utilize these systems as refuge zones and nurseries. The difference, however, lies between the principal source of energy and how it is incorporated in the food web of each ecosystem. Lake Nokoué is a detritus-driven ecosystem while Ébrié lagoon is dominated by the phytoplankton pathway. System indicators suggest different levels of ecosystem stability and maturity. Relevance of other observations on ecosystem functioning and indicators in relation to perturbation is discussed.
\end{abstract}

Keywords: Tropical lagoons; West Africa; Transfer efficiency; System maturity; Ecopath 


\section{Introduction}

Coastal lagoons are considered as some of the most productive aquatic ecosystems due to high levels of primary production, inten se reserve of organic matter and habitat diversity that offer op timal niches for numerous aquatic species which utilize these areas as refuge and/or breeding grounds (Yáñez-Arancibia et al., 1994; Silvestre and Pauly, 1997; Baran and Hambrey, 1998; Berger et al., 1999; Baran, 2000; Blaber, 2002; Krause and Glaser, 2003; Lalèyè et al., 2003c; Glaser and da Silva Oliveira, 2004). According to Duarte (1995), productions in coastal lagoons are 10-15 times higher than tho se of other continental shelves.

(1)

On the West African coastline, these ecosystems are generally shallow with highly varying gradients. As transitional areas with intense fluctuations of environmental conditions, these ecosystems influence complex multi-species dynamics and impose physiological constraints on biota (Baran, 2000). The ecosystem structure has been observed to depend on freshwater bio-geographic regions, as well as on river discharges and hydrological regimes (Écoutin, 1992; Winemiller, 1995; Baran and Hambrey, 1998; Guiral, 1999; Welcomme, 1999; Baran, 2000). The occurrence and production of the system's living resources are seasonally variable in relation to the marine and/or continental water flows into these 'intermediate' systems. Regional climate trends seem to influence the species diversity of the lagoon community where communities of estuarine species decrease as the species of salt marshes increase.

The establishment of increasing human populations near lagoons, gulfs and bays has resulted in significant degradation and loss of coastal wetlands (Adingra and Arfi, 
1998; Entsua-Mensah, 2002; Ibe and Sherman, 2002; Scheren et al., 2002; Glaser, 2003). Construction and practice of traditional forms of low-technology aquaculture, such as brush-parks or acadjas, in coastal lagoons and brackish waters in many areas of the world were to alleviate fish production to meet increas ing demand for national consumption and export (Beardmore et al., 1997; Welcomme, 2002; Lalèyè, 2000;

Lalèyè et al., 2003c). Chan ges in environmental conditions generally provoke diverse biological processes or responses (i.e. competition or food depletion) leaving more tolerant species to persist while less tolerant species are eliminated (Berger et al., 1999; Baran and Hambrey, 1998; Laegdsgaard and Johnson, 2001; Glaser, 2003).

\section{5}

58

\section{For this study, two West African lagoons, Ébrié lagoon and Lake Nokoué, are} considered. Previous ecological and biological information on these ecosystems exist such as Durand et al (1994), Adité and Winemiller (1997) and Lalèyè et al (2003c). However, as far as we know, no broad general synthesis of a multi-specific analysis and the combined influence of their characteristics (i.e. production, mortality, trophic interactions, adaptations) following environmental changes has yet been published to date.

5

This study attemp ts to summarize and integrate existing data and to depict a larger picture of in teractions among biological components and how abiotic conditions mould their structure, metabolism and function in the ecosystem using a mas s-balanced modelling software, Ecopath (Christensen et al., 2000). Focus is attributed on quantification of biomass flows and transfer efficiencies among trophic levels (TLs) and identification of significant trophodynamic links occurring between groups (Christensen, 1998). Mod elling ecological systems can be useful in describing how an ecosystem is 
organized and assessing species relation ship stability and diversity through complex but tractable depictions of energy transfers, trophic fluxes, assimilation efficiencies and dissipation. Results can provide critical insights that can be further utilized to evaluate the impacts of changes in abundance of a particular group on other groups (ArreguínSánchez, 2000) and verify multi-species management decisions and conservation (Baird and Ulanowicz, 1993; Beck et al., 2001; Glaser and da Silva Oliveira, 2004).

\section{Research approach}

\section{Study sites}

Ébrié lagoon (Ivory Coast) (Fig. 1, left) is a complex, elongated, open coastal lagoon system located between longitudes $3^{\circ} 47^{\prime} \mathrm{W}$ and $5^{\circ} 29 \mathrm{~W}$ and latitudes, $5^{\circ} 02^{\prime} \mathrm{N}$ and $5^{\circ} 42^{\prime} \mathrm{N}$. It has a total area of $566 \mathrm{~km}^{2}$ and the lagoon stretches to about $130 \mathrm{~km}$ and a maximum width of $7 \mathrm{~km}$. Annual precipitation in Abidjan is about $1800 \mathrm{~mm}$. The average water depth is 4.8 meters though depths of $20 \mathrm{~m}$ can be observed near Abidjan. The average water temperature is $28^{\circ} \mathrm{C}$. Water from the Atlantic Ocean penetrates the lagoon through the Vridi canal $(300 \mathrm{~m})$ and mixes with freshwater discharges from three connecting rivers: Comoé, Agnéby and Mé (Laë, 1997a; Pagano et al., 2003).

Lake Nokoué (Fig. 1, right) is a shallow, sub-tropical co astal lagoon $\left(6^{\circ} 25^{\prime} \mathrm{N}\right.$, $1^{\circ} 56$ 'E) with a surface of $150 \mathrm{~km}^{2}$ and stretches $20 \mathrm{~km}$ in its east-west direction by 11 $\mathrm{km}$ in the north-south direction. Lake Nokoué opens directly into the Atlantic Ocean by a channel at Cotonou $(4.5 \mathrm{~km})$ and it is connected with the Porto-Novo lagoon to its East by the $5 \mathrm{~km}$ Totché channel. Saltwater and marine organisms gain access into the lake through the Cotonou channel. Annual precipitation in Cotonou was recorded at 1300 
$\mathrm{mm}$. The average depth of the lake varies from $1 \mathrm{~m}$ (dry season) to $3 \mathrm{~m}$ (rainy season).

The av erage water temperature is $29^{\circ} \mathrm{C}$. Spatial and temporal variations of hydrological parameters were studied in detail by Adité (1996) and recently by Adounvo et al. (2003) and by Lalèyè et al. (2003a).

\section{Model construction}

The Ecopath software is a model based on a set of simultaneous linear equations for each group considered in an ecosystem and assumes a mass balance where the production of the group is equal to the sum of all predations, non predatory loses and exports (Christensen et al., 2000). Integration of different ecological levels (i.e. individual, population and community) is pertinent in ecosystem modelling. In order to minimize in formation loss and taxonomic bias es, biological compon ents are pooled according to similarities of species trophic properties (i.e. diets, predators and metabolic activity) and distribution (Yodzis and Winemiller, 1999). Each trophic group has an energy balance expressed as:

$$
B_{i}\left(\frac{P}{B_{i}}\right)=\sum_{j=1}^{n} B_{j}\left(\frac{Q}{B_{i}}\right)-D C_{j i}+\left(B_{i}\right)\left(\frac{P}{B_{i}}\right)\left(1-E E_{i}\right)+E X_{i}
$$

where $B_{i}$ is the biomass of group $i ; P / B_{i}$ is the production rate of $i$ equal to the total mortality coefficient $\left(Z\right.$ ) (Allen, 1971); $Q / B_{i}$ is the relative consumption rate; $B_{j}$ is the biomass of the predating group $j ; D C_{j i}$, the proportion of the predated group $i$ in the diet of the predating group $j ; E E_{i}$ is the ecotrophic efficiency representing the part of the total production transferred to higher TLs through predation or captured in the fisheries; $E X_{i}$ export or catch in fisheries of group $i$, assumed exploited in fisheries. 
Mass-balanced models used here were those previously developed by Villanueva

125 (2004). A total of 42 and 31 functional groups were considered for Ébrié and Nokoué,

126 respectively (Tables 1 and 2). For these models, input data used were mainly from

127 primary data collected and complemented by existing literatures (Niyonkuru et al., 2003;

128 Simier et al., 2003) from specific study sites and considering the same period to achieve

129 proper model synchronization. The choice of the study period was based on the

130 availability and abundance of data for each ecosys tem considered, as well as on periods

131 marked by considerable fishing and hydrologic variations. For trophic groups with

132 several species, estimates were derived from properties of the dominant species

133 summarized in table 1.

134

135 Biomasses were expressed and standardized as annual average in tons of wet

136 weight (ww) $\mathrm{km}^{-2}$. Production and consumption rates were compiled from a variety of

137 sources and detailed in tables 1 and 2. Flows between compartments are given in tons of

138 wet weight $\mathrm{km}^{-2} \mathrm{yr}^{-1}$.

139

140 Diet composition of functional groups considered for each models was compiled

141 by Villanueva (2004) and are summarized in tables 3 and 4. It should be highlighted that

142 most of these data were based on biological and ecological studies made in each

143 ecosystem. The landings data used for the Ébrié and Nokoué models were taken from

144 Écoutin et al. (1994) and the Department of Fisheries in Cotonou surveys, respectively.

145

146 The Ecoranger routine was used to test the sensitivity of each models

147 constructed. This routine limits possible technical errors as it adjusts accordingly 
148 possible input parameters that can be modified depending on the data source and

149 calculates the impact on the resulting estimates. This is useful in refining less accurate

150 data, such as in the case of the Ébrié model where most qualitative data on diet

151 composition were modified accordingly to decrease uncertainties or to achieve an

152 ecotrophic efficiency $(E E)$ value of less than 1.

153

154 Network description analysis

155 A. structural analyses

156

157 Group omnivory index (OI) is a concept introduced by Pauly et al (1993) which

158 incorporates the TL variations of different preys consumed by a predator. $O I$ values near

1590 indicate a highly specialized predator while 1 indicates groups with considerable 160 versatility.

161

162

163

164

165

166

167

168

169

170

171

172

Lindeman (1942) introduced the concept of describing food webs based on grouped taxa and quantified energetic flows of organic matters by TLs which allow assessment of energy transfer efficiency. TL is a dimensionless index that identifies what kinds of food an organism uses. This is a simplification of the food-web to determine the distribution of net input and output flows in each group that has contributed to the next TL. This concept is a useful abstraction to clarify and organize understanding of en ergy transfer in ecosystems and overcome bias in differing number of biological components when comparing ecosystem state and functioning. In Ecopath, group aggregations into discrete TLs (Ulanowicz, 1986) were carried out based on approach suggested by Ulanowicz (1995). TLs are represented as fractions (Odum \& Heald, 1975) rather than in tegers $(1,2,3 \ldots)$ as initially proposed by Lindeman. 
179 fisheries concentrate on high TLs. This index may increase with fisheries 'development'

180 as indicated by Pauly et al. (1998).

181

182

The total system throughput (TST) is defined as the sum of all flows in a system. It represents the "size of the entire system in terms of flow" (Ulanowicz, 1986). As such, it is an important parameter for comparisons of flow networks.

The ratio of total system biomass to the total system throughput $(B / \mathrm{TST})$

(Christensen, 1995) is directly proportional to system maturity where estimated value tends to be low during ecosystem development phase and increases as a function of maturity. Energy is conserved through component energy stocking (Odum, 1971; Ulanowicz, 1986).

The ratio of Net Primary Production to Total Respiration (PP/TR) is another system maturity in dex (Odum, 1969; Pérez-España and Arreguín-Sánchez, 1999) where values of this ratio close to 1 indicate mature ecosystems.

\footnotetext{
The net production of the system (NPP-TR) is another index of system maturity
} (Odum, 1969) and should be zero out in a truly balanced ecosystem. 
The system omnivory index $(S O I)$ is computed as the average omnivory index of

200 all consumers weighted by the logarithm of each consumer's food intake (Christensen et 201 al., 2000).

The connectance index $(C I)$ for a given food web is the ratio of the number of

204 actual links between groups to the number of theoretically possible links. Feeding on

205 detritus (by detritivores) is included in the count, but the opposite links (i.e., detritus

206 'feed ing' on other groups) are disregarded. This ind ex is correlated with the maturity of

207 the ecosystem because a food chain structure changes from linear to web-like as a system 208 matures (Odum, 1969; 1971).

Initially considered by Finn (1976), the Finn's cycling index is the proportion of

211 the total system throughput (TST) recycled in the system. According to Monaco and

212 Ulanowicz (1997), cycling is considered to be an important indicator of an ecosystem's

213 ability to maintain its structure and integrity through positive feedback and can be used as

214 an indicator of stress (Ulanowicz, 1986) or system maturity (Christensen, 1995;

215 Vasconcellos et al., 1997). This is similar to the predatory cycling index, which is

216 calculated by excluding the cycling through detritus. Disturbed systems are characterized

217 by short and fast cycles while complex trophic structures have long and slow ones

218 (Odum, 1969; Kay et al., 1989; Christensen, 1995). A manner of quantifying the length

219 of each cycle is through the Finn's mean path length which accounts for the number of

220 groups involved in a flow. Finn's straight-through path length (excluding detritus) is

221 another indicator of ecosystem health wherein a low value translates a stressed ecosystem 222 and a short food chain controlled by bottom-up forces. 
Macro-descriptors are typically applied for large and complex ecosystems whose

225 aim is to present ecosystem growth and development (Ulanowicz, 1997). Ascendancy, $A$,

226 (Ulanowicz, 1986) and mutual information, $I$, (Hirata, 1995) are examples of quantitative

227 descriptors that differ from those used in classical food webs. Ascendancy is a measure of 228 system growth (i.e. age, size) and development (i.e. organization) of network links. The

229 fraction of a system's capacity not considered as ascendancy is considered as the systems

230 overhead, which is the energy in reserve of an ecosystem (Monaco and Ulanowicz,

231 1997), especially in case of perturb ations (Ulanowicz, 1986). The relative ascendancy

$232(A / C)$ is the fraction of possible organization that is actually realized (Ulanowicz, 1986)

233 and it is negatively correlated with maturity (Christen sen, 1995).

\section{Results}

After integrating all the basic inputs, both models were balanced. Basic parameterization results for the Ébrié and Nokoué models are shown in tables 1 and 2, respectively, whereas the feeding matrices are displayed in tables 3 and 4.

Model sensitivity

Pedigree indices of 0.79 and 0.75 for Nokoué and Ébrié models, respectively

243 were obtained from the model. Both values conform to the gauge of the overall quality

244 of an Ecopath model as discussed by Christensen et al. (2000). The Ecoranger routine

245 was then used for each model in order to assess their viability. For the Ébrié model, 33

246 acceptable runs out 10000 were obtained with a least sum of deviation equal to 16.06 . A

247 higher number of accep table runs (158/10 000) were obtained for Lake Nokoué with a 
248 least sum of deviation equal to 11.27. These values indicated that both models are

249 tightly-fitted. The in itial inputs and outputs based on our field data were very close to the

250 mean values generated by Ecoran ger. Ratios of respiration to assimilation $(R / A)$,

251 production to respiration $(P / R)$ and estimated $E E$ s for all considered group are less than 2521.

253

254 Structural analyses corresponding to groups 1, 4 and 5 and with most fish groups (75\%) at TL3 (Table 1). In Nokoué, ind ividual TL varied between 3.5 and 1.0 with the highest value corresponding to group 5 followed by groups 2, 4, 13 and 15 (Table 2). acadjas which are artificial fish aggregating devices built using branches that act both as

264 a insatiable food source for detritivores (such as tilapias and benthic organisms), as well as lowering predation and competition pressure by limiting access of carnivores or

266 piscivores (Welcomme, 1999). predation rates of some groups depending on the environmental conditions and Group $O I$ values obtained are quite low and may be due to the specialization and

271 Nokoué may be due to possible feeding of non- or less-detritivorous groups on detritus 272 because of eutrophication and limited access to other prey types due to acadjas 
273 installations, covering most of the lake's surface. It is interesting to no te that eight

274 groups in Ébrié lagoon occupy higher TLs and have $O I$ values greater than 0.25 ,

275 compared to only 5 groups in Lake Nokoué. Among these are the mobile epiben thos,

276 such as the blue swimming crab (Callinectes latimanus) and pink shrimps (Penaeus

277 duorarum), which consume plankton, benthos, crustaceans and organic materials.

278

279 Trophic network analysis

It is important to note that, in terms of fish and crustacean, biomasses and

282 ecological production in TL3 are higher than in TL2 for the Ébrié lagoon model,

283 whereas, the opposite is observed in Lake Nokoué (Table 5 and Figure 2). The

284 proportions of species of these various groups are quite similar in both systems and fish

285 assemblages seem to have common patterns even if their relative importance, in terms of

286 biomass, is highly variable. In the Ébrié model, $71.5 \%$ of the fish biomass is at TL3 or

287 higher such as Sardinella maderensis (6.0 \%), Gerres spp (3.0\%), Chrysichthys

288 nigrodigitatus (11.0\%), Dasyatis spp (3.0\%) and Tylochromis jentinki (4.0\%). In Lake

289 Nokoué, on the other hand, only $38.0 \%$ of the total fish biomass belongs to TL3 or

290 higher. The key groups are below TL2.5: the tilapiine fish (55.0\%), Gobiids (12.0\%)

291 and E. fimbriata (32.0\%).

Transfer efficiencies decline at higher TLs in both ecosystems considered (Figure

294 3) which is similar to observations of Manickchand-Heileman et al. (1998) and Zetina-

295 Rejón et al. (2003). The transfer efficiency is higher in Ébrié than in Nokoué for TL2, 3

296 and 4. This is in relation to the difference of structure of the fish community in both

297 ecosystems as noted in table 5 and figure 3. The geometric mean transfer efficiency was 
$298 \quad 15.5$ and $10.3 \%$ for Ébrié lagoon and Lake Nokoué, respectively. Proportion of total

299 flow originating from detritus is $44 \%$ in Ébrié lagoon compared to $72.0 \%$ in Lake

$300 \quad$ Nokoué.

301

302 Trophic interspecific reactions for Ébrié lagoon and Lake Nokoué are shown in

303 figures 3a and b, respectively. For the Ébrié model, the total consumption is estimated at

$3041,207.68 \mathrm{tkm}^{-2} \mathrm{yr}^{-1}$ (Table 6) where $71.5 \%\left(740.4 \mathrm{tkm}^{-2} \mathrm{yr}^{-1}\right)$ of the flow from TL1 to

305 TL2 originates from the producers whereas dead decaying materials contribute only 28.5

$306 \%\left(294.6 \mathrm{tkm}^{-2} \mathrm{yr}^{-1}\right)$ (Figure 3a). It results in a detrivory: herbivory ratio (D:H) of 1:2.5

307 (Figure 3a). Most phytoplanktonic production is incorporated into the food web by

308 zooplankton and zoobenthos.

309

310 In Lake Nokoué, the total food consumption, which is higher than in Ébrié

311 lagoon, is estimated at 25,713.42 $\mathrm{tkm}^{-2} \mathrm{yr}^{-1}$ (Table 6). Figure $3 \mathrm{~b}$ shows that energy

312 transferred from TL1 is accessed mainly from the detritus $\left(19,242.1 \mathrm{tkm}^{-2} \mathrm{yr}^{-1}\right)$ as

313 compared to that coming from the primary production $\left(4,133.7 \mathrm{tkm}^{-2} \mathrm{yr}^{-1}\right)$. It results in a

314 D:H ratio of $4.6: 1$ (Figure $3 b$ ).

315

316 The highest flow back to detritus was observed from the autotrophs, (TL1)

$3171,889.6 \mathrm{tkm}^{-2} \mathrm{yr}^{-1}$, in the Ébrié lagoon and from primary consumers (TL2), $12,167.7 \mathrm{tkm}^{-}$

$318{ }^{2} \mathrm{yr}^{-1}$, in Lake Nokoué (Figure $3 \mathrm{a}$ and $\mathrm{b}$ ).

319

320 The SOI value and the connectance index $(C I)$ are lower in Ébrié $(0.145$ and

3210.191 , respectively) than in Nokoué (0.156 and 0.266, respectively) (Table 6). These 
322 indicate that Lake Nokoué has a more web-like feature of trophic structure than in Ébrié 323 lagoon.

The mean TL of catch is 2.88 in Ébrié lagoon and is 2.46 in Lake Nokoué (Table

326 6). This is mainly due to the different relative importance of key-targeted groups in the

327 fisheries occupying different TLs in each system as can be observed from tables 1, 2, 5

328 and 6. This has also an influence on the gross efficiency $(G E)$ of the catch: lower in Ébrié 329 (0.004) than in Nokoué (0.009). Total system throughput for each ecosystem (Table 6 ) is 330 higher in Lake Nokoué than in Ébrié lagoon.

$333(P / R)$ ratio near 1 indicates an ecosystem approaching maturity (Odum, 1969).

334 Comparing the values obtained in each model (Table 6), Ébrié is a less mature system 335 (5.055) than Nokoué where $P / R$ is near 1 (1.126). Considering other attributes of 336 ecosystem maturity and stability ( $B / \mathrm{TST}$, TPP/TR, PP-TR, PP/B), values obtained for 337 Lake Nokoué indicates that this ecosystem is reaching a mature stage and is therefore 338 more stable.

340 Energy and matter recycling is considered as an important process in ecosystem 341 functioning (Odum, 1969) and is measured as FCI. According to Heymans and Baird 342 (2000), value of this index is between 4.0 to $15.0 \%$ for coastal ecosystems. Estimated 343 FCI value (Table 6) in Lake Nokoué (34.0\%) is much higher than in Ébrié lagoon (2.7 $344 \%)$. It is, however, relatively low compared to that obtained by Manickchand-Heileman 345 et al. (1998). The high value of Finn's straight-through path length (excluding detritus) 
346 in Nokoué suggests a short food chain perhaps due to shifting of diets of other groups

347 towards detritivory.

348

\section{Discussion}

350

As in any Ecopath model, the outputs and the consequent uncertainties of results

352 are strongly related to input parameters integrated. The viability of the Ecopath models

353 was determined by using the sensitivity analyses, i.e. Pedigree index and Ecoranger,

354 incorporated in the software (Christensen et al., 2000). The high viability observed for

355 each model considered, as indicated by the high pedigree indices, was due to the

356 consideration of input parameters estimated mostly from specific studies in the

357 considered ecosystems (i.e. Durand et al., 1994; Adingra and Arfi, 1998; Albaret, 1999;

358 Lalèyè et al., 2003a, b, c; Simier et al., 2003; Adounvo et al., 2005). Since most of the

359 data were based on direct observations, results ind icate that both models are tightly-fitted

360 as simulations give allocating values which have no remarkable difference from original

361 inputs.

362

Fishes and macroinvertebrates are very good environmental indicators to track

364 environmental health and ecological changes as adaptive response to stress, especially in

365 estuaries and lagoons (Paugy and Bénech, 1989; King, 1993; USEPA, 2000). Comparing

366 tables 1 and 2, several taxonomic groups are similarly represented in both models.

367 Similarities of common and endemic biological assemblages are possibly due to close

368 geographical location though dissimilarities, especially in biodiversity, are mainly due to

369 hydrologic dynamics (Winemiller, 1995; Guiral, 1999). However, these taxonomic

370 species occupy differing TL in each ecosystem. Winemiller (1990) indicated that similar 
resources are utilized by species of comparable morphological traits. However, according to Polis et al. (1996) resource utilization and ecological interactions are high ly dependent on habitat heterogeneity and may explain deviation in trophic guilds and behaviors of similar taxonomic groups in different ecosystems.

$$
\text { though indicated a considerable quantity of detritus in its diet in Ébrié lagoon. Charles- }
$$
Dominique (1982) explained that the presence of decaying materials in its stomach coincides mainly to strong river run-offs. Observations in Lake Nokoué, on the other hand, indicate that this species is considerably feeding on decaying materials and, to a lesser degree, on plankton. (1)

(feed ing on algae, periphyton and organic matter) has been indicated by several authors (Pauly et al., 1988; Paugy, 1990), as well as its ability to adapt in terms of growth and reproduction to varying and extreme environmental conditions, i.e. ability to grow in reefs of undergrowth, limited oxygen supply (Adité and Winemiller, 1987; Duponchelle et al., 1998; Panfili et al., 2004; Pauly 2002; Villanueva, 2004). This species has already been observed to acclimate fast in several West African brackish systems such as in Sakumo lagoon (Pauly, 2002), Ébrié lagoon (Konan-Brou and Guiral, 1994), TohoTodougba lagoon (Adité and Winemiller, 1997) and in Sine Saloum estuary (Panfili et al., 2004). The high productivity and resilience of this species to stress may also be attributed to the presence of "acadjas" which act as an extensive aquaculture system (Konan-Brou and Guiral, 1994) that increase trophic efficiency of the lagoon, i.e. suitable places for breeding, low predation and niche competition (Adité and 
396 Winemiller, 1997; Laë, 1997b; Welcomme, 1999; Lalèyè, 2000; Villanueva, 2004). In

397 Ébrié lagoon, S. melanotheron is present though less abundant and has a higher

398 probability of occurrence concentrated in stenohaline and euryhaline sectors of the

399 lagoon (Villanueva, 2004). Abundance and occurrence of this species may be influenced

400 by river discharges which increas es availability of food similar to observations of Adité

401 and Win emiller (1997).

402

These ecosystems are characterized by complex food webs and high eco-

404 physiological capacities of biologic communities against extremely varying

405 environmental conditions, in space and time (Carrada and Fresi, 1988; Albaret and

406 Écoutin, 1990; Adité and Winemiller, 1997; Lalèyè et al., 2003b; Berlow et al., 2004;

407 Villanueva, 2004). Levels of fish structure organizations in these ecosystems are never

408 high (Albaret and Écoutin, 1990) though Laë (1997b) observed that re-structurization of

409 food web occurs in the case of environmental stress. Higher structural organization is

410 observed in Ébrié lagoon (highest TL 3.9) than in Lake Nokoué (TL 3.2) which is due to

411 lower biodiversity in the latter ecosystem.

412

413 Numerous studies have suggested that biodiversity reduces variability in

414 eco system productivity through compensatory effects (Naeem and Li, 1997; Loreau,

415 2000; Berlow et al., 2004), which means that a species increases in abundance in

416 response to the reduction of another in a fluctuating environment. A high biodiversity

417 enhances an ecosystem's reliability through increase in redundant species per functional

418 group where some groups occupying a given TL maintain ecosystem functioning by

419 compensating for temporary loss of other groups in the same TL. The system integrity of

420 Lake Nokoué seems to be assured against biod iversity loss and other perturbations 
421 through further simplification of food web structure and increased recycling of organic

422 matter. According to Loreau et al (2000), low species richness does not necessarily entail

423 weakened ecosystem properties and services. In Ébrié lagoon, diversity and production

424 are positively correlated where differences in distribution and eco-physiological

425 characteristics increase efficiency of energy utilization thus maintain ecosystem integrity

426 through function replacement of some groups by others in the same TL.

ecosystems was noted by Albaret (1999). De Sylva (1985) indicated that estuarine

nektons follow either a detritus-based or a phytoplankton-based food chain. Primary

producers and detritus are energy sources that play differing roles and significance in the

435 Sund arban mangrove system (India). Macrophytes, on the other hand, provide shelter for

436 crustaceans and mollusks. Paugy and Bénéch (1989) observed that in such environments,

437 the latter is less important. This is not the case, however, in Lake Nokoué where the

438 detrital pathway dominates over the grazing pathway similar to Orbetello lagoon studied

439 by Brando et al (2004) and the Terminos lagoon (Arreguín-Sánchez et al., 1993;

440 Manickchand-Heileman et al., 1998). These dead organic materials sustain large

441 biomasses of benthos by providing substrates for ep iphytes and shelters for crustaceans

442 and mollusks (Zetina-Rejón et al., 2003; Moore et al., 2004). The high biomass of TL1

443 (detritus and primary producers) and its significant role in supporting the energy utilized 444 indicate a bottom-up control in both ecosystems. 
In Lake Nokoué D:H ratio is high despite the absence of micro-organ isms (i.e.

447 bacteria) among the considered functional groups in the system. This high detritus

448 consumption is mainly due to the high density of $S$. melanotheron in this ecosystem.

449 Adite and Winemiller (1997) indicated that reduction of available resources in Lake

450 Nokoué due to environmental degradation may have contributed to changes of ecological

451 interactions and ecosystem physiography leading to a relative increase of detritivores.

452

The importance of detritiv ory in Lake Nokoué is due to dietary shifts of carnivore species such as the C. nigrodigitatus, E. fimbriata, Trachinotus ovatus and Liza falcipinnis to a more detritus-based feeding when other resources are limited (Adité and Winemiller, 1997) and which may compete with the true detritivores, the tilapias ( $S$. melanotheron and T. guineensis). Other fish species in TL2, as well as ep ibenthos (crabs and shrimps) are directly utilizing this resource (Figure 3b).

\section{Ecosystem functioning can be better viewed in terms of biomass fluxes between} TLs. Predators and resource availability can cause direct chan ges of diversity from one TL to the next (Nielsen, 2001). This suggests that the flow rates between predators and preys may vary as a function of limiting conditions or variables (i.e. seasonal variations; availability of food).

In Lake Nokoue the link from TL1 to higher TLs is formed mainly by zoobenthos (i.e. bivalves), decapod crustacea and fishes (i.e. tilapias) while the zooplankton (dominated by rotifers) seems to be less important. According to Gnohossou (2001), the predominance of rotifers among zooplankton populations clearly indicates intense fishing activity in Lake Nokoué. Similar observation s have been indicated by A. Duncan 
471 (RHUL, pers. comm.) in an artificial lake in Sri Lanka. Rotifers seem to be poorly

472 consumed and may contribute to the high flow of TL2 back to the detritus (Figure 4b). In

473 Ébrié lagoon, the zooplank ton group has a positive effect on most other groups and

474 serves as a principal link between primary producers and high er consumers (Villanueva,

475 2004) similar to that was observed by Zetina-Rejón et al. (2003) in Huizache-Caimanero

476 lagoon complex, Mexico. Other groups, such as the decapod crustacea (i.e. shrimps and

477 crabs) and zoobenthos, feed considerably on both phytoplankton production and detritus.

478

479

According to Heymans et al (2002) the amount of energy flowing through the

480 detrital pathway can equal or exceed that observed from grazers. The low transfer

481 efficiencies in Lake Nokoué may be aggrav ated by the presence of acadjas which limits

482 predation (biomass transfer flow from TL2 mainly from S. melanotheron to higher TLs

483 is reduced) resulting significant flows back to detritus (Figure 3b) similar to indications

484 of Moore et al (2004). Poor utilization of primary production, zooplankton and even $S$.

485 melanotheron by other groups in higher TLs is indicated by the low troph ic efficiency of

486 phytoplankton (Table 6) and the large flows back to detritus of TL1 (primary

487 production) and TL2 (F igure 3b). According to Gnohossou (UAC, pers. data), rotifers

488 are rarely found in food items ingested by fish, especially in plankton-feeding species

489 such as E. fimbriata. Blaber (2000) indicated that th is species is a visual-filtrer and high

490 water turbidity levels in Nokoué may decrease its feeding efficiency. Inefficient grazing

491 by herbivores has already been observed in other ecosystems such as continental shelf

492 area in Sierra Leone (Longhurst, 1983) and Terminos Lagoon, Mexico (Manickchand-

493 Heileman et al., 1998).

494 
Estimated total system throughputs (Table 6) in both ecosystems are rather high

496 compared to that obtained by Carrer and Optiz (1999) in the Palude della Rosa lagoon,

497 Venice. TST in Ébrié lagoon $\left(6,240 \mathrm{tkm}^{-2} \mathrm{yr}^{-1}\right)$ is comparable to that estimated by

498 Manickchand-Heileman et al (1998) in Terminos lagoon (Mexico). For Lake Nokoué;

499 TST value $\left(57,967 \mathrm{tkm}^{-2} \cdot \mathrm{yr}^{-1}\right)$ is high compared to the two ecosystems mentioned above

500 and also with comparable systems for instance some coastal ecosystems reported by

501 Christensen and Pauly (1993) though relatively lower than that obtained by Lin et al

502 (1999) in a Chiku lagoon, Taiwan.

503

504

505

506

507

508

509

510

511

512

513

514

515

516

517

518

519

Estimated production levels in both ecosystems, however, are higher than those in eco systems such as Terminos Lagoon, Mexico (Arreguín-Sánchez et al., 1993;

Manickchand-Heileman et al., 1998). Rec ent surveys made by the Department of

Fisheries in Cotonou (Benin) showed that annual yield in Lake Nokoué alone reaches

about $19,500 \operatorname{tyr}^{-1}\left(1.5\right.$ tha $\left.^{-1}\right)$ which is 10 times more than in Ébrié lagoon. $S$.

melanotheron forms about $77.0 \%$ of this catch (Lalèyè, 2000). This may explain the

higher gross efficiency $(G E)$ value calculated in Nokoué (0.009) compared to Ébrié

(0.004) (Table 6). Écoutin et al. (1994) indicated that considerable fish and crustacean

exploitations already occurred from the late 1970 s to the early 1980 s which resulted in a

remarkable depletion of annual catch in the Ébrié lagoon (Laë, 1997a). GE values are,

however, lower than the values obtained by Lin et al. (1999) for a sand barrier lagoon in

Chiku, Taiwan. According to Jarre-Teichmann (1998), cost of fish exploitation in

ecological terms is less at lower TLs than those at higher ones.

Assemblages in Lake Nokoué had shown a greater interspecific resource partitioning than in Ébrié lagoon though it is important to consider that factors 
520 influencing dietary diversity (seasonal dietary shifts, spatial variations in dietary habits, 521 etc.) which may have influenced our analyses. According to Heymans et al. (2004), a

522 low value of $C I$ coupled with a slightly elevated $S O I$ value may indicate an ecosystem

523 less dependent on detritus as a source of energy. This is essentially the case in Ébrié

524 lagoon (Table 6). The higher $C I$ and SOI values estimated in Lake Nokoué ind icate that

525 it is more stable and has a higher resilience to stress than in Ébrié lagoon despite a

526 higher biodiversity of the latter.

Coastal systems such as lagoons are characterized by complex food webs and

529 high eco-physiological capacities of biologic communities against extremely varying

530 environmental conditions, in space and time (Carrada and Fresi, 1988; Albaret and

531 Écoutin, 1990; Adité and Winemiller, 1997; Lalèyè et al., 2003b; Berlow et al., 2004;

532 Villanueva, 2004). They are dynamic rather than static systems where change and

533 disturbance are seen as natural features of these ecosystems (Bengtsson et al., 2000)

534 which seem paradoxal when described as stable systems. Ecosystem stability can be

535 quantified from changes and dynamics (i.e. thermodynamics, productivity) of its

536 components and dimensions where stability is seen as a basis against which ecosystem's

537 responses to perturbation is measured (Christensen, 1995; Nilsson and Grelsson, 1995;

538 Gunderson 2000), such as in mature systems (Odum, 1969). It is argued that the stability,

539 of an ecosystem is high if the connectance (weighted number of nonzero entries in the

540 flow matrix) of the energy flow network is high (Grimm et al., 1992; Berlow et al., 541 2004).

543 Lake Nokoué may be more stable due to the increased re mineralization of organic 544 materials in this ecosystem compared to that in the Ébrié lagoon. High detrivory in 
545 Nokoué may mitigate resource limitations caused by env ironmental change. Moore et al

546 (2004) indicated that a detritus-based ecosystem is more stable both in terms of energy

547 fluxes and consumer population dynamics. Detritus can alter en ergy and effect nutrient

548 transfer efficiencies across trophic levels and increase persistence and food web stability.

549 According to Hairston and Hairston (1993) detritus impinge on the trophic structure and

550 community dynamics as well as supports a vast diversity of species supporting larger

551 predator biomass and longer food chains compared to ecosystems supported merely by

552 living autotrophs.

553

554 The implantation of acadjas in many Asian and African countries is mainly due to

555 its great potential in enhancing technologies, annual yield as well as alleviating social and

556 economic welfares by providing food, employment and livelihood rapidly to the growing

557 population (Costa and Wijeyaratne, 1994; Wahab et al., 1999; COFAD GmbH, 2002;

558 Lalèyè, 2000; Lorenzen et al., 2001; Ekram-Ul-Azim et al., 2002). According to Sokorin

559 et al (1996) and Lalèyè (2000), the high productivity of coastal lagoons is due to the

560 intense bacterial re-mineralization of organic matters and the continuous circulation of

561 water and sediment nutrients. The presence of the acadjas contributes to the production of

562 organic materials to support the ecosystem despite low primary production from

563 phytoplankton and terrestrial vegetations (Konan-Brou and Guiral, 1994; Welcomme,

564 1999) and replicates artificially favored habitats by certain species offering shelter from

565 predators, suitable breeding grounds (Lalèyè, 2000) aside from the high abundance of

566 food.

567

568 While this type of periphyton-based aquaculture can be conducted in sustainable

569 ways, increasing productivity has been achieved with considerable environmental costs, 
570 threatening many aquatic and marine ecosystems (Lalèyè et al., 2001). Nutrient addition

571 in ecosystems which increases productivity often lead to lower species richness as more

572 productive species outcompete less productive ones (Waide et al. 1999). Lalèyè (2000)

573 indicated that although the number and areas covered by acadjas in Benin have increased

574 their productivity has decreased over the years $\left(5.625\right.$ t.ha. $^{-1} \mathrm{yr}^{-1}$ in $1959 ; 3.9$ t.ha. $^{-1} \mathrm{yr}^{-1}$ in

$5751970 ; 4.1$ t.ha. $^{-1} \mathrm{yr}^{-1}$ in 1981 and 1.92 t.ha. $\left.^{-1} \mathrm{yr}^{-1}, 1998\right)$ mainly due to the decline in

576 density and quality of branches used.

577

578

579

580

581

582

De Silva (1998) indicated that aquacultures depend on two critical environmental factors: quality and quantity of water. These factors, in turn, depend upon an ecosystem's assimilative capacity for wastes and replenishment of oxygen (Beveridge et al., 1997). It was noted by Lalèyè et al. (2003a) that in Lake Nokoué, dissolved oxygen reaches 0 during the night indicating that oxygen is totally utilized by the system (high respiration rates). High oxygen depletion in other coastal lagoons in the Gulf of Guinea has also been indicated by Scheren et al. (2002). The TPP/TR ratio in Lake Nokoué (1.126) indicates a level close to "eu trophic status" as total sys tem respiration approaches its production, which is a common feature in highly polluted systems. Ébrié lagoon seems less eutrophic due to its higher TPP/TR ratio (5.155) which may be due to lower pollution loads during the period (early 80 's) considered for this study. This may be no longer true if based on recent environmental domestic and industrial pollution loads indicated by Scheren et al. (2002) in this lagoon compared to coastal waters in Benin. According to Mann et al. (1989), system ascendancy (A) and TST can also be used as indicators of eutrophication in ecosystems. This is characterized by an increased value in $A$, as a function of elevated TST parallel to a fall in information (I) (Ulanowicz, 1986). In 
594 Lake Nokoué, an elevated $A(47,224$ flowbits) is compensated by a low value of $I(0.815)$

595 compared to that in Ébrié where $A$ is 7,656 flowbits with an $I$ of 1.147 (Table 6).

596

597

598

599

600

601

602

603

604

605

606

607

608

609

610

611

612

613

614

615

616

617

\section{Conclusion}

Coastal ecosystems function is a life support system of poor populations and their destruction is a real cause of growing poverty and deprivation relating to a whole spectrum of economic and social problems (John and Lawson, 1990; Ibe and Sherman, 2002; Scheren et al., 2002; Lalèyè et al., 2003c). The most reported detrimental impacts are conversion of wetlands, destruction of valuable habitats (i.e. mangrove forests), loss of biodiversity, pollution of local waters, biological discharge of waste nutrien ts, rivalry between endemic and introduced exotic species and amplified pressure on natural wild stock (Beardmore et al., 1997; Baran and Hambrey, 1998; Berger et al., 1999; Lalèyè, 2000; Laegds gaard and John son, 2001; Scheren et al., 2002; Glaser, 2003). Apart from various industrialized and agricultural activities, over-fishing is responsible for a wide variety of impacts on fish communities including even modification of population composition and ecosystem adaptations to a changing environment due to stress conditions.

West African coastal ecosystems, as well as in most part of the world, have experienced both long-term trends and rapid environmental changes. Recent accelerating human impacts have brought in other elements that prevent predictions of impact resulting from change. Associated organisms have evolved under these changing environmental conditions and have responded to past natural disturbances, i.e. climate 
618 change and species interactions, with ad aptation or migration while others have become

619 extinct.

620

Based on the present study, phytoplanktonic production showed a positive effect

622 in supporting groups in higher TLs in the Ébrié lagoon while detritus played a major role

623 in Lake Nokoué. Ébrié lagoon showed a greater ecological diversification and higher

624 structural organization of biological communities due to higher species assemblages

625 leading to favorable patterns of reliable flows. Lake Nokoué on the other hand, is more

626 stable and shows more signs of maturity mainly due to the abundance of tolerant species

627 that drive the recovery processes after perturbation.

628

The relationship discussed between organism functions, environments and

630 responses to stress have implications for understanding environmental perturbations on

631 ecological communities. It is evident that ecosystem changes cause a profound

632 restructuring of local communities which can not be predicted without a clear

633 understanding of the mechanisms that retain species' ass emblages and functions. The

634 value of an ecosystem-based evaluation, as elucidated here, should be important not only

635 for basic science but for anticipating the likely impacts of environmental perturbations on

636 ecosystem functions and socio-economic challenges they may involve.

637

638 Acknowledgements

639

640 This work was partly carried out during M.C. Villanueva's thesis work at the

641 Institut National Polytechnique de Toulouse (INPT). The authors are grateful to M.

642 Bouvy, J.-M. Écoutin and M. Pagano (Institut de Recherche pour le Développement, 
643 IRD), P. Gnohossou and C. Niyonkuru (University of Abomey-Calavi, UAC), G.

644 Gourène and O. Ouattara (Université d'Abobo-Adjamé, UAA) and A. Dauta (Centre

645 National de Recherche Scientifique, CNRS) for valuable contributions. M.C. Villanueva

646 gratefully acknowledges V. Christensen and C. Ainsworth of the Fisheries Centre

647 (University of British Columbia) for helpful comments on modelled ecosystems. This

648 contribution was supported by an IRD project entitled, "Réponses adaptives des

649 populations et peuplements de Poissons aux pressions de l'environnement (RAP)", and a

650 UAC-CAMPUS project $n^{\circ}$ 99.00.26 entitled, "Fonctionnement écologique d'une lagune

651 ouest africaine, lac Nokoué au Bénin". Lastly, we would like to thank the anonymous

652 referees whose comments have greatly improved the quality of this work.

653

654 References

655

656 Adingra, A.A., Arfi, R. 1998. Organic and bacterial pollution in the Ébrié lagoon, Côte

657 d'Ivoire. Mar. Pollution Bull. 36 (9), 689-695.

658 Adité, A. 1996. Evolution des parameters physico-chimiques des principaux plans d'eau

659 du sud-Bénin (1987-1991). Rapport de travaux realises pour le compte du Projet

660 Pêche Lagunaire-GTZ, Bénin 1, 180 p.

661 Adité, A., Winemiller, K.O. 1997. Trophic ecology and ecomorphology of fish

662 assemblages in coastal lakes of Benin, West Africa. Ecoscience 4 (1), 16-23.

663 Adounvo, U., Dauta A., Lalèyè P., Villanueva M.C., Moreau J. 2005. Primary production

664 in Lake Nokoué. Paper presented in the International Conference of the French

665 Association of Limnology [Association Français de Limnologie, AFL], « Connaître

666 les écosystèmes d'eau douce pour mieux les gérer (CILO) ». 
667

668

669

670

671

672

673

674

675

676

677

678

679

680

681

682

683

684

691

Albaret, J.-J. 1999. Les peuplements des estuaires et des lagunes. In Lévêque, C., Paugy, D. (Eds.), Les poissons des eaux continentales africaines: div ersité, écologie, utilisation par l'homme. Éditions de l'IRD, Paris, pp. 325-349.

Albaret, J.-J., Écoutin, J.-M. 1990. Influence des saisons et des variations climatiques sur les peuplements de poissons d'une lagune tropicale de l'Afrique de l'Ouest. Acta Oecologia 11, 557-583.

Arreguín-Sánchez, F., Valero-Pacheco, E., Chávez, E.A. 1993. A trophic box model of the coastal fish communities of the southern Gulf of Mexico. In Christensen, V., Pauly, D. (Eds.), Trophic models of aquatic ecosystems. ICLARM Conf. Proc. 26, 197-213.

Banse, K., Mosher, S. 1980. Adult body mass and annual production/biomass of field populations. Ecol. Monogr. 50 (3), 335-379.

Baran, E. 2000. Biodiversity of estuarine fish faunas in West Africa. Naga. 23(4), 4-9.

Baran, E., Hambrey, J. 1998. Mangrove conservation and coastal management in Southeast Asia: what impact on fishery resources? Mar. Pollution Bull. 37 (8-12), 431-440.

Beardmore, J.A., Mair, G.C., Lewis, R.I. 1997. Biodiversity in aquatic systems in relation to aquaculture

Beck, M.W., Heck, K.L. Jr., Able, K.W., Childers, D.L., Eggleston, D.B., Gillanders, B.M., Halpern, B., Hays, C.G., Hoshino, K., Minello, T.J., Orth, R.J., Sheridan, P.F., Weinstein, M.P. 2001. The identification, conservation and management of estuarine and marine nurseries for fish and invertebrates. Bioscience 51, 633-641.

Bengts son, J., Nilsson, S.G., Fran c, A., Menozzi, P. 2000. Biodiversity, disturbances, ecosystem function and management of European forests. Forest Ecol. Manage. $132,39-50$. 
Berger, U., Glaser, M., Koch, B., Krause, G., Lara, R., Saint-Paul, U., Schories, D., Wolff, M. 1999. An integrated approach to man grove dynamics and management. J. Coastal Cons. 5, 125-134.

Berlow, E. L., Neutel, A.-M., Cohen, J.E., De Ruiter, P.C., Ebenman, B., Emmerson, M., Fox, J.W., Jansen, V.A.A., Jones, J.I., Kokkor is, G.D., Logofet, D.O., Mckane, A.J., Montoya, J.M., Petchey, O. 2004. Interaction strengths in food webs: issues and opportunities. J. Anim. Ecol. 73, 585-598.

Beveridge, M.C.M; Phillips, M.J., Macintosh, D.J. 1997. Aquaculture and the environment: The supply of and demand for environmental goods and services by Asian aquaculture and the implication for sustainability. Aquaculture Res. 18, 797807.

Blaber, S.J.M. 2000. Tropical estuarine fishes: Ecology, exploitation and conservation. Blackwell Science Ltd., Oxford.

Blaber, S.J.M. 2002. Fish in hot water: the challenges facing fish and fisheries research in tropical estuaries. J. Fish Biol. 62 (supplement A), 1-20.

Brando, V.E., Ceccarelli, R., Libralato, S., Ravagnan, G. 2004. Assessment of environmental management effects in a shallow water basin using mass-balance models. Ecol. Model. 172, 213-232.

Cap Blanc, J., Dauta, A. 1999. Photosynthesis simulator ver 2.1. CNRS, Toulouse.

Carrada, G.C., Fresi, E. 1988. Le lagune salmastre costiere. Alcune riflessioni sui problemi e sui metodi. In Carrada, G.C., Cicogna, F., Fresi, E. (Eds.), Le lagune costiere: ricerca e gestione. CLEM, Massa Lubrense, pp. 35-56.

Carrer, S., Optiz, S. 1999. Trophic network model of a shallow water area in the northern part of the lagoon of Venice. Ecol. Model. 124, 193-219. 
716 Christen sen, V. 1995. Ecosystem maturity — towards quantification. Ecol. Model. 77, $717 \quad 3-32$.

718 Christen sen, V. 1998. Fishery-induced changes in a marine ecosystem: insight from the 719 models of the Gulf of Thailand. J. Fish Biol. 53, 128-142.

720 Christensen, V., Pauly, D. (Eds). 1993. Trophic Models of Aquatic Ecosystems, 721 ICLARM Conf. Proc. Vol. 26, Manila.

722 Christensen, V., Walters, C.J., Pauly, D. 2000. Ecopath with Ecosim: A user's guide. 723 October 2000 Edition. Fisheries Centre, University of Bristish Columbia, 724 Vancouver, Can ada and ICLARM, Penang, Malaysia.

725 Charles-Dominique, E. 1982. Exposé synoptique des données biologiques sur 726 l'ethmalose (Ethmalosa fimbriata, S. Bowdich, 1825). Rev. Hydrobiol. Trop. 15(4), $727 \quad 373-397$.

728 COFAD GmbH 2002. Back to Basics: Traditional inland fisheries management and 729 enhancement systems in sub-Saharan Africa and their potential for development. 730 Deutsche Gesellschaft für Technische Zusammenarbeit (GTZ) GmbH. Eschborn, 731203 p.

732 Costa, H.H., Wijeyaratne, M.J.S. 1994. Utilization of mangrove species in brushpark 733 construction and their effect on Negombo Estuary fishery (Sri Lanka). J. Appl. $734 \quad$ Ichthyol. 10, 96-103.

735 De Merona, B. 1983. Modèle de croissance des poissons d'eaux douces d'Afrique. Rev. 736 Hydrobiol. Trop. 19, 1-12.

737 De Silva, S.S. 1998. Tropical aquaculture: Current status and prospects, pp. 17-59. In De 738 Silva, S.S. (Ed.), Tropical aquaculture. Academic Press, Cornwall, England. 
De Sylva, D.P. 1985. Nektonic food webs in estuaries. In Yáñez-Arancibia, A. (Ed.), Fish community ecology in estuaries and coastal lagoons: Towards ecosystem integration. UNAM Press, Mexico, pp. 233-246.

Diallo, I., Cissé I., Bah, A. 2003. Modèle trophique du système côtier du plateau continental Guinéen. In Pauly, D., Palomares M.L., Vakily, J.M. (Eds.), Trophic Models of Northwest African Marine Ecosystems. SIAP/EP/DT/03, pp. 98-115.

Dufour, P. 1994. Les microphytes, pp 109 -136. In Durand, J.-R., Dufour, P., Guiral, D., Zabi, S.G.F. (Eds.), Environnement et ressources aquatiques de Côte d'Ivoire. Tome II - Les milieux lagunaires. ORSTOM, Paris.

Duarte, C.M. 1995. Submerged aquatic vegetation in relation to different nutrient regimes. Ophelia 41, 87-112.

Duponchelle, F., Pouyaud, L., Legendre, M. 1998. Evidence of environmental effects on reproductive characteristics of Nile tilapia (Oreochromis niloticus) populations from man-made lakes of Ivory Coast. Aquat. Living Res. 11 (3), 137-144.

Durand, J.-R., Dufour, P., Guiral, D., Zabi, S.G.F. (Eds.). 1994. Environnement et ressources aquatiques de Côte d'Ivoire. Tome II - Les milieux lagunaires. ORSTOM, Paris.

Écoutin, J.-M., Durand, J.-R., Laë, R., Hié Daré, J.P. 1994. L’exploitation des stocks. In Durand, J.-R., Dufour, P., Guiral, D., Zabi, S.G.F. (Eds.), Environnement et ressources aquatiques de Côte d'Ivoire. Tome II - Les milieux lagunaires. ORSTOM, Paris, pp. 399-444.

Ekram Azim, M., Wahab, M.A. Verdegem, M.C.J., van Dam, A.A., van Rooij, J.M., Beveridge, M.C.M. 2002. The effects of artificial substrates on freshwater pond productivity and water quality and the implications for periphyton-based aquaculture. Aquat. Living Resour. 15, 231-241. 
764 Entsua-Mensah, M. 2002. The contribution of coastal lagoons to the continental shelf 765 ecosystem of Ghana. In McGlade, J.M., Cury, P., Koranteng, K.A., Hardman766 Mountford, N.J. (Eds.), The Gulf of Gu inea Large Marine Ecosystems, Elsevier 767 Science, Amsterdam, pp. 161-187.

768 Finn, J.T. 1976 Measures of ecosystem structure and function derived from analysis. J. 769 Theo. Biol. 56, 363-380.

770 Froese, R., Binohlan, C. 2000. Empirical relationships to estimate asymptotic length, 771 length at first maturity and yield at maximum yield per recruitment in fishes, with a 772 simple method to evaluate length frequency data. J. Fish Biol. 56, 758-773.

773 Froese, R., Pauly, D. (Eds). 2004. Fishbase. World Wide Web electronic publication: $774 \quad$ http://www.fishbase.org

775 Garcia, S. 1977. Evaluation des mortalités chez la crevette rose, Penaeus notialis, en 776 Côte-d'Ivoire: analyse des variations saisonniéres de capturabilité. Cah.

777 O.R.S.T.O.M., ser. Océanogr., 15(3), 251-260.

778 Gayanilo, F.C. Jr., Sparre, P., Pauly, D. (Eds.) 2002. The FAO-ICLARM Stock

779 Assessment Tools II (FiSAT II Ver. 1.0). FAO. Site URL:

$780 \quad$ http://www.fao.org/fi/statist/fisoft/fisat

781 Glaser, M. 2003. Interrelations between mangrove ecosystem, local economy and social 782 sustainability in Caeté Estuary, North Brazil. Wetlands Ecol. Manage. 11, 265-272.

783 Glaser, M., da Silva Oliveira, R. 2004. Prospects for the co-management of mangrove 784 ecosystems on the North Brazilian coast: Who se rights, whose duties and whose 785 priorities ? Nat. Res. Forum 28, 224-233.

786 Gnohossou, P. 2002. Influence de la pollution organique sur les invertébrés du lac 787 Nokoué. Mémoire de D.A.A. Institut National Polytechnique de Toulouse/ENSAT, $788 \quad 48 \mathrm{p}$. 
789 Grimm, V., Schmidt, E., Wissel, C. 1992. On the application of stability concepts in $790 \quad$ ecology. Ecol. Modell. 63, 143-161.

791 Guiral, D. 1999. Les écosystèmes à mangroves. In Comier-Salem, M.-C. (Ed.), Rivières 792 du Sud: sociétés et mangroves ouest-africaines. Éditions IRD, Paris, pp. 63-130. 793 Guiral, D., N’Da Étien,. 1994. Les macrophytes. In Durand, J.-R., Dufour, P., Guiral, D., 794 Zabi, S.G.F. (Eds.) Environnement et res sources aquatiqu es de Côte d'Ivoire. 795 Tome II - Les milieux lagunaires. ORSTOM, Paris, pp 137-154.

796 Gunderson, L.H. 2000. Ecological resilience in theory and application. Ann. Rev. Ecol. $797 \quad$ System. 31, 425-439.

798 Hairston, N.G. Jr., Hairston, N.G. Sr. 1993. Cause effect relationsh ips in energy flow, 799 trophic structure, and interspecific interactions. Am. Nat., 142, 379-411. 800 Heymans, J.M., Baird, D. 2000. Network analysis of the Northern Benguela eco system 801 by means of NETWRK and Ecopath. Ecol. Model. 131, 97-119.

802 Heymans, J.J., Shannon, L.J., Jarre, A. 2004. Changes in the northern Benguela 803 ecosystem over three decades: 1970s, 1980s and 1990s. Ecol. Modell. 172, 175$804 \quad 195$.

805 Heymans, J.J., Ulanowicz, R.E., Bondavalli, C. 2002. Network analysis of the South 806 Florida Everglades graminoid marshes and comparison with nearby cypress 807 ecosystems. Ecol. Model. 149, 5-23.

808 Hirata, H. 1995. Information theory and ecological networks. In: Patten, B.C., Jørgensen, 809 S.E., Auerbach, S.I. (Eds.), Complex ecology: The part-whole relation in 810 ecosystems. Prentice Hall PTR, New Jersey, pp. 623-642.

811 Ibe, C., Sherman, K. 2002. The Gulf of Guinea Large Marine Ecosystem Project: Turning 812 challenges into achievements. In McGlade, J.M., Cury, P., Koranteng, K.A., 
Hardman-Mountford, N.J. (Eds.), The Gulf of Guinea Large Marine Ecosystem.

814 Elsevier Science B.V., Amsterdam, pp. 27-39.

815 Jarre-Teichmann, A. 1998. The potential role of mass-balanced models for the

816 management of upwelling ecosystems. Ecol. App. 8 (1), 93-103.

817 John, D.M., Lawson, G.W. (1990). A review of mangrove and coastal ecosystems in

818 West Africa and their possible relationships. Est. Coast. Shelf Sci. 31, 505-518.

819 King, R.P. 1993. Seasonal plasticity in faunal dietary status, diversity and foraging

820 performance of Ilisha africana (Clupeidae) in Qua Iboe estuary, Nigeria. Cybium

$821 \quad 17(4), 287-298$.

822 Kay, J.J., Graham, L.A., Ulanowicz, R.E. 1989. A detailed guide to network analysis. In

823 Wulff, F., Field, J.G., Mann, K.H. (Eds.), Network Analysis in Marine Ecology:

824 Methods and Applications. Springer-Verlag, Berlin, pp. 15-60.

825 Konan-Brou, A.A., Guiral, D. 1994. Available algal biomass in tropical brackish water

826 artificial habitats. Aquaculture 119, 175-190.

827 Laë, R. 1997a. Does overfishing lead to a decrease in catches and yields? An example of 828 two West African Coastal Lagoons. Fish. Manage. Ecol. 4, 149-164.

829 Laë, R. 1997b. Effects of climatic changes and developments on continental fishing in 830 West Africa: the examples of the Central delta of the Niger in Mali and coastal 831 lagoons in Togo. In Remane, K. (Ed.), African Inland fisheries, aquaculture and 832 environment. FAO, Italy, pp. 66-86.

833 Laegdsgaard, P. Johnson, C. 2001. Why do juvenile fish utilise mangrove habitats? J.

$834 \quad$ Exp. Mar. Biol. Ecol. 257, 229-253.

835 Lalèyè, P. 2000. Acadja fisheries enhancement systems in Benin: Their productivity and 836 environmental impacts. In Abban, E.K., Casal, C.M.V., Dugan, P., Falk, T.M. 
(Eds), The World Fish Center/ICLARM. Biodiversity and sustainable use of fish in

838 the coastal zone. ICLARM Conf. Proc. 63, 51-52.

839 Lalèyè, P., Adounvo, U., Niyonkuru, C., Villanueva, M.C., Moreau, J. 2003a. Spatio-

840 temporal variations of some water physico-chemical parameters in Lake Nokoué

841 (Benin), recent evolutions. Abstract. Third International Conference of the

842 PanAfrican Fish and Fisheries Association, Cotonou, Benin 10-14 November 2003.

843 Lalèyè, P., Chikou, A., Niyonkuru, C., Moreau, J. 2001. The acadjas in Lake Nokoué and

844 Porto-Novo lagoon (Benin, West Africa): Influence of an artificial substrat on

845 natural fish populations: a quantitative analysis. Proceedings of the $2^{\text {nd }}$ Symposium

846 for the European Freshwater SEFS2, 8-13 July 2001, Toulouse.

847 Lalèyè, P., Niyonkuru, C., Moreau, J., Teugels, G. 2003b. Spatial and seasonal

848 distribution of the ichtyofauna of Lake Nokoué, Benin, West Africa. Afr. J. Aquat.

$849 \quad$ Sci. $28,151-161$.

850 Lalèyè, P., Philippart, J.C. 1997. Contribution à l'écologie du Lac Nokoué/Lagune de 851 Porto-Novo au Bénin. Abstract, p 121. $5^{\text {ème }}$ Conférence Internationale des 852 Limnologues d'expression française. CILEF5, Namur, Belgique, 6 - 11 July 1997.

853 Lalèyè, P., Villanueva, M.C., Moreau, J., Enstua-Mensah, M. 2003c The lagoons of the 854 Gulf of Guinea: a review of the current knowledge of their aquatic resources and 855 management issues. Abstract. Third International Conference of the PanAfrican 856 Fish and Fisheries Association, Cotonou, Benin 10-14 November 2003.

857 Lhomme, F. 1994. Les crustacés exploitables. In Durand, J.-R., Dufour, P., Guiral, D., 858 Zabi, S.G.F. (Eds.), Environnement et ressources aquatiques de Côte d'Ivoire.

859 Tome II - Les milieux lagunaires. ORS TOM, Paris, pp. 229-238. 
Lin, H.-J., Shao, K.-T., Kuo, S.-R., Hsieh, H.-L., Wong, S.-L., Chen, I.-M., Lo, W.-T., Hung, J.-J. 1999. A trophic model of a Sandy Barrier Lagoon at Chiku in Southwestern Taiwan. Est. Coast. Shelf Sci. 48, 575-588.

Longhurst, A. 1983. Benthic-pelagic coupling and export of organic carbon from a tropical Atlantic Continental shelf - Sierra Leone. Est. Coast. Shelf Sci. 17, 261285.

Loreau, M. 2000 Biodiversity and ecosystem functioning: Recent theorectical advances. Oïkos 91, 3-17.

Lorenzen, K., Amarasinghe, U.S., Bartley, D.M., Bell, J.D., Bilio, M., de Silva, S.S., Garaway, C.J., Hartmann, W.D., Kapetsky, J.M. Lalèyè, P., Moreau, J., Sugunan, V.V., Swar, D.B. 2001. Strategic review of enhancements and culture-based fisheries. In Subasinghe, R.P., Bueno, P., Phillips, M.J., Hough, C., McGladdery, S.E. (Eds.), Aquaculture in the Third Millenium. Technical Proceedings of the Conference on Aquaculture in the Third Millenium, Bangkok, Thailand, 20-25 February 2000, pp. 221-237.

Mann, K.H., Field, J.G. and Wulff, F. 1989. Network analys is in marine ecology: an assessment. In: F. Wulff, J.G. Field and K.H. Mann (Eds.), Network Analysis in Marine Ecology. Methods and Applications. Springer-Verlag, Berlin, pp. 261-282.

Manickchand-Heileman, S., Arreguín-Sánchez, F., Lara-Domínguez, A., Soto, L.A. 1998. Energy flow and network analysis of Terminos Lagoon, SW Gulf of Mexico. J. Fish Biol. 53, 179-197.

Monaco, M.E., Ulanowicz, R.E. 1997. Comparative ecosystem trophic structure of three U.S. mid-Atlantic estuaries. Mar. Ecol. Prog. Ser. 161, 239-254.

Moore, J.C., Berlow, E.L., Coleman, D.C., de Ruiter, P.C., Dong, Q., Hastings, A., Collin s Johnson, N., Mc Cann, K.S., Melville, K., Morin, P.J., Nadelhoffer, K., 

Detritus, trophic dynamics and biodiv ersity. Ecol. Lett. 7, 584-600.

Naeem, S., Li, S. 1997. Biodiversity enhances ecosystem reliability. Nature, 390, 507509.

Nielsen, K.J. 2001. Bottom-up and top-down forces in tide pools: test of a food chain model in an intertidal community. Ecol. Monographs. 71, 187-217.

891 Nilsson, C., Grelsson, G. 1995. The fragility of ecosystems: A review. J. Appl. Ecol. 32, 892

Niyonkuru, C. 2001. Etudes des variations spatio-temporelles de la faune ichtyologique

Niyonkuru, C., Lalèyè, P., Villanueva, M.C., Moreau, J. 2003. Population parameters of main fish species of Lake Nokoué in Benin. Abstract. Third International

Odum, E.P. 1969. The strategy of ecosystem development. Science 104, 262-270. 
908 Palomares, M.L.D., Pauly, D. 1998. Predicting food consumption of fish populations as

909 functions of mortality, food type, morphometrics, temperature and salinity. Mar.

$910 \quad$ Freshwater Res. 49, 447-453.

911 Panfili, J., Mbow, A., Durand, J.-D., Diop, K., Diouf, K., Thior, D., Ndiaye P., Laë, R.

912 2004. Influence on the life-history traits of the West African black-chinned tilapia

913 (Sarotherodon melanotheron): Comparison between the Gambia and the Saloum

914 estuaries. Aquat. Living Res. 17, 65-74.

915 Paugy, D., Bén ech, V. 1989. Les poissons d'eau douce des bassins côtiers du Togo

916 (Afrique de l’Ouest). Rev. Hydrobiol. Trop. 22 (4), 295-316.

917 Pauly, D. 1976. The biology, fishery and potential for aquaculture of Tilapia

918 melanotheron in a small West African lagoon. Aquaculture 7, 33-49.

919 Pauly, D. 2002. Spatial modelling of trophic interactions and fisheries impacts in coastal

920 ecosystems: A case study of Sakumo lagoon. In McGlade, J.M., Cury, P.,

921 Koranteng, K.A., Hardman-Mountford, N.J. (Eds.), The Gulf of Guin ea Large

922 Marine Ecosystem. Elsevier Science B.V., Amsterdam ,pp. 289-296.

923 Pauly, D. Soriano-Bartz, M., Palomares, M.L.D. 1993. Improved construction,

924 parametrization and interpretation of steady-state ecosystem models. In Christensen

925 V., Pauly, D. (Eds.), Trophic models of aquatic systems. ICLARM Conf. Proc. 26,

$926 \quad 1-13$

927 Pauly, D., Christensen, V., Dalsgaard, J., Froese, R., Torres, Jr. F.C. 1998. Fishing down

928 marine food webs. Science 279, 860-863.

929 Pauly, D., Palomares, M.L.D., Moreau, J. 1988. Detritus and energy consumption and

930 conversion efficiency of Sarotherodon melanotheron (Cichlidae) in a West African

931 lagoon. J. App. Ichthyol. 4, 190-193. 
932 Pérez-España, H., Arreguín-Sánchez, F. 1999. A measure of ecosystem maturity. Ecol.

$933 \quad$ Model. 119, 79-85.

934 Ray, S., Ulanowicz, R.E., Majee, N.C., Roy, A.B. 2000. Network analysis of a benthic

935 food web model of a partly reclaimed island in the Sundarban mangrove system,

$936 \quad$ India. J. Biol. Syst. 8(3), 263-278.

937 Scheren, P.A., Ibe, A.C., Janssen, F.J., Lemmens, A.M. 2002. Environmental pollution in

938 the Gulf of Guinea: a regional approach. Mar. Pollut. Bull. 44, 633-641.

939 Silvestre, G., Pauly, D. 1997. Management of tropical coastal fisheries in Asia: an

940 overview of key challenges and opportunities. In Silvestre, G., Pauly, D. (Eds.),

941 Status and management of tropical coastal fisheries in Asia. ICLARM Conf. Proc.

$942 \quad 53,8-25$.

943 Simier, M., Écoutin, J.-M., Ndiaye, E. 2003. Pêchexp 2003: Base de Données RAP,

944 Volet Pêches Expérimentales : Notice descriptive. IRD Document Interne, Dakar, $945 \quad 38 \mathrm{p}$.

946 Sorokin, Y.I., Sorok in, P., Giovanardi, O., Dalla Venezia, L., 1996. Study of ecosystem 947 of the Lagoon of Venice, with emphasis on anthropogenic impact. Mar. Ecol. Progr. $948 \quad$ Ser. 141, 247-261.

949 Thayer, G.W, Schaff, W.E., Angelovic, J.W., LaCroix, M.W. 1973. Caloric

950 measurements of some estuarine organisms. Fish. Bull. 71 (1), 289-296.

951 Ulanowicz, R.E. 1986. Growth and development. Ecosystem phenomenology. Springer-

$952 \quad$ Verlag, Berlin.

953 Ulanowicz, R.E. 1987. NETWRK: a package of computer algorithms to analyze

954 ecological flow networks. 4. University of Maryland, Solomons. 
955 Ulanowicz, R.E. 1995. The part-whole relation in ecosystems. In Patten, B.C., Jorgensen,

956 S. E., Auerbach, S.I. (Eds.), Complex ecology. Prentice Hall, New Jersey, pp. 549-

$957 \quad 560$.

958 Ulanowicz, R.E. 1997. Ecology, the ascend ant perspective. Columbia University Press, $959 \quad$ New York.

960 USEPA. 2000. Estuarine and coastal marine waters: Bioassessment and biocriteria 961 technical guidance . U.S. Environmental Protection Agency Report EPA-822-B00962 024, Washington D.C.

963 Van Thielen, R. 1990. Visite du Lac Nokoué: une introduction à la pêche au Bénin.

964 Projet Pêche Lagunaire (Bénin). A GTZ Project. Available in the Deparment of $965 \quad$ Fisheries, Cotonou.

966 Vasconcellos, M., Mackinson, S., Sloman, K., Pauly, D., 1997. The stability of trophic 967 mass-balance models of marine ecosystems - a comparative analysis. Ecol. Model. $968 \quad 100,125-134$.

969 Villanueva, M.C. 2004. Biodiversité et relations trophiques dans quelques milieux $970 \quad$ estuariens et lagunaires de l'Afrique de l'Ouest: adaptations aux pressions 971 environnementales. Thèse de Doctorat. Institut National Polytechnique de 972 Toulouse, $246 \mathrm{p}+\mathrm{CD}$ [URL site : http://ethesis.inp-toulouse.fr/archive/00000115]. 973 Waide, R.B., Willig, M.R., Steiner, C.F., Mittelbach, G., Gough, L., Dodson, S.I., Juday, 974 G.P., Parmenter, R. 1999. The relationship between productivity and species 975 richness. Annu. Rev. Ecol. Syst. 30, 257-300.

976 Wahab, M. A., Azim, M.E., Ali, M.H., Beveridge, M.C. M., Khan, S. 1999. The potential 977 of periphyton-based culture of the native major carp calbaush, Labeo calbasu 978 (Hamilton). Aquaculture Res. 30, 409-419. 
979 Welcomme, R.L. 1999. A review of a model for qualitative evaluation of exploitation $980 \quad$ levels in multi-species fisheries. Fish. Manage. Ecol. 6, 1-19.

981 Welcomme, R.L. (2002) An evaluation of tropical brush and vegetation park fisheries. $982 \quad$ Fish. Manage. Ecol. 9, 175-188.

983 Winemiller, K.O. 1995. Aspects structurels et fonctionnels de la biodiversité des 984 peuplements de poissons. Bull. Fr. Pêche Piscic. 337/338/339, 23-45.

985 Wulff, F., Ulanowicz, R.E. 1989. A comparative anatomy of the Baltic Sea and 986 Chesapeake ecosystems. In Wulff, F., Field, J.G., Mann, K.H. (Eds.), Network 987 analysis in Marine Ecology. Methods and Applications. Springer-Verlag, Berlin, $988 \quad$ pp. $232-256$.

989 Yáñez-Arancibia, A., Dominguez, L.L., Pauly, D. 1994. Coastal lagoons as fish habitats.

990 In Kjerfve (Ed.), Coastal lagoon processes. Elsevier Oceanog. Ser. 60, 363-376.

991 Yodzis, P., Winemiller, K.O. 1999. In search of operational trophospecies in a tropical 992 aquatic food web. Oikos. 87, 327-340.

993 Zetina-Rejón, M. J., Arreguín-Sánchez, F., Chávez, E. A. 2003. Trophic structure and 994 flows of en ergy in the Huizache-Caimanero lagoon complex on the Pacific coast of 995 Mexico. Estuar. Coastal Shelf Sci. 57, 1-13. 
Legends of figures:

Figure 1. The Lagoon Ébrié in Ivory Coast (left) and the Lake Nokoue in Benin (right).

Figure 2. Detailed trophic structure of biomass ( $\mathrm{km}^{-2}$, left $)$ and ecologic production ( $\mathrm{tkm}^{-2} \mathrm{yr}^{-1}$, right), of fish groups as summarized using Ecopath: (a) Lagoon Ébrié and (b) Lake Nokoué.

Figure 3. Simplified trophic flow models of Lagoon Ébrié (A) and Lake Nokoué (B) showing discrete trophic levels. Detritus (part of TL I) has been separated to show its significance as energy source in each ecosystem. Percentage (\%) values indicate trophic efficiencies per trophic level. Numbers on arrows indicate flow of energy expressed in $\mathrm{tkm}^{-2} \mathrm{yr}^{-1}$. 


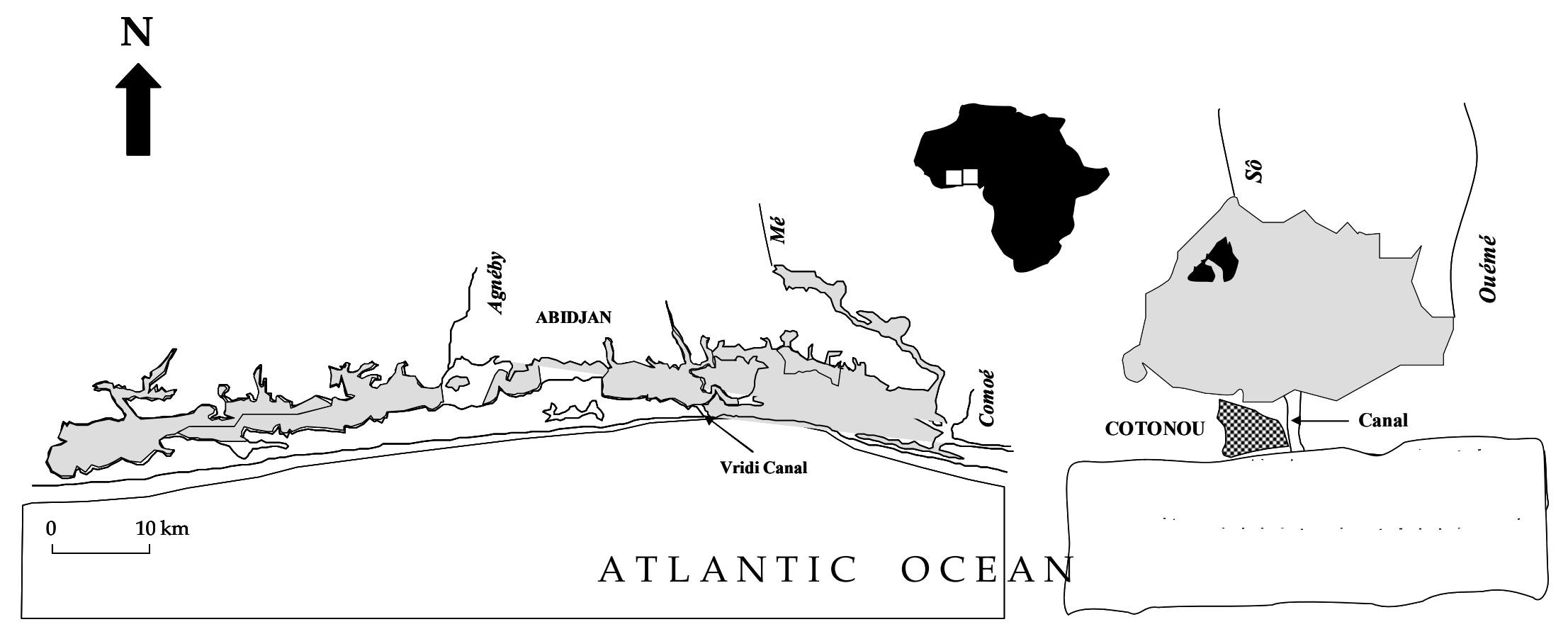

Figure 1

Villa nueva et al. 
A.

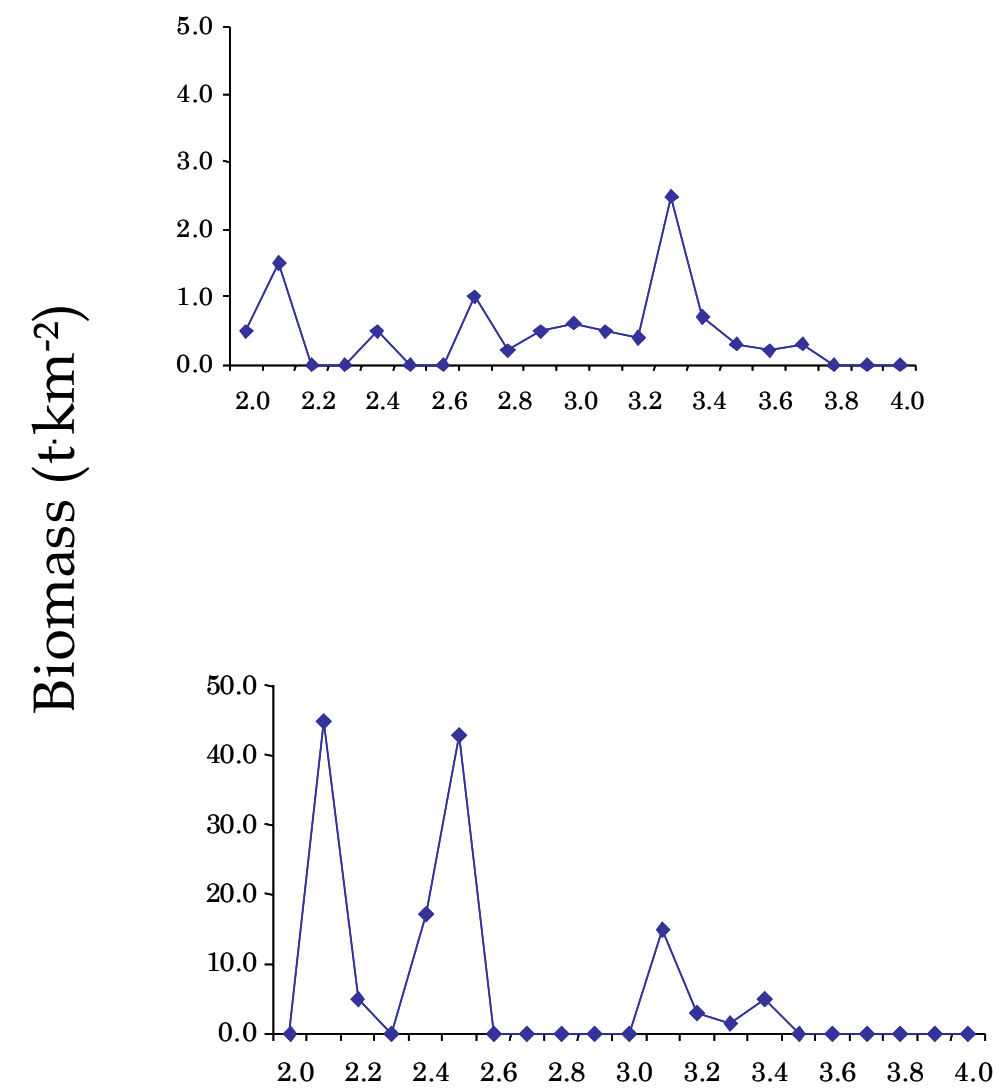

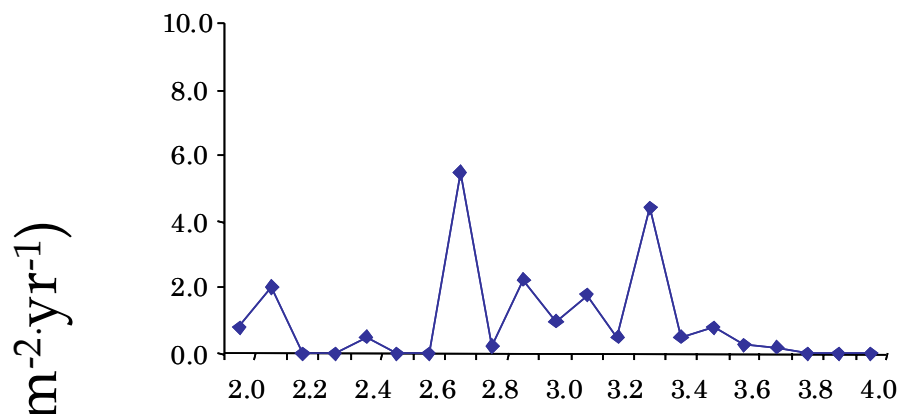

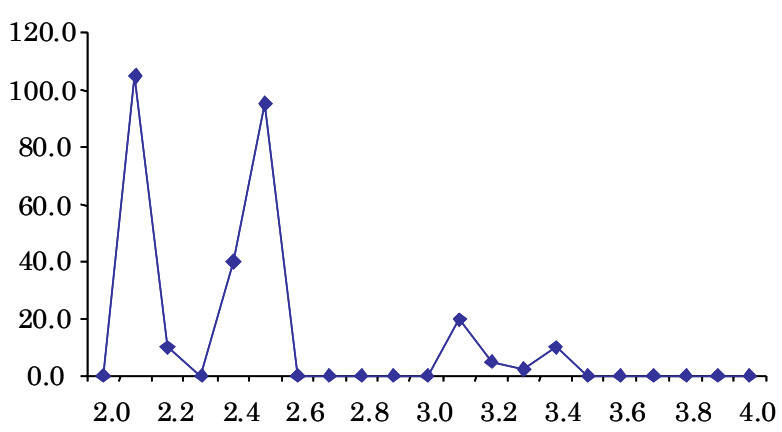

\section{Trophic level}

Figure 2

Villanueva et al. 

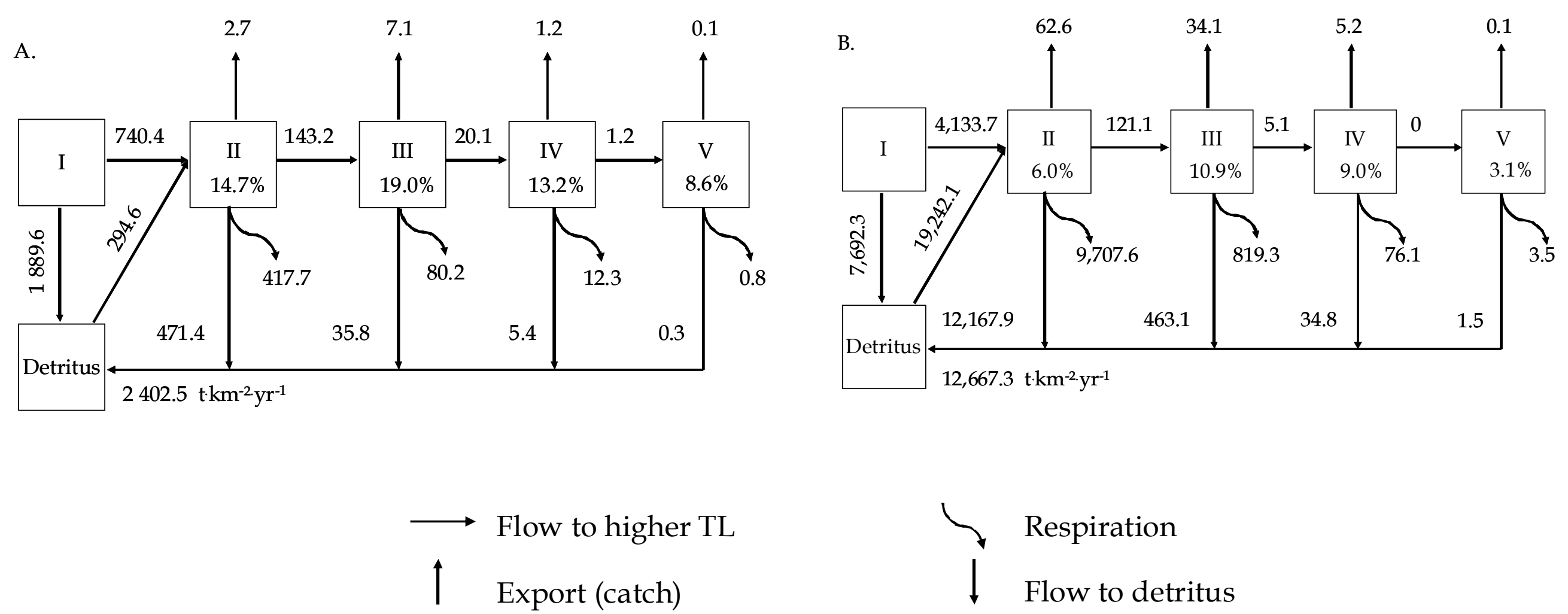

Figure 3

Villa nueva et al. 
Table 1. Basic inputs and estimated outputs (bold) of the Ébrié lagoon model during the early eighties.

\begin{tabular}{|c|c|c|c|c|c|c|c|}
\hline & Group name & TL & $\boldsymbol{B}$ & $P / B$ & $Q / B$ & $\boldsymbol{Y}$ & $O I$ \\
\hline 1 & Sphyraena afra* & $(3.9)$ & 0.010 & 2.060 & 8.427 & 0.020 & 0.204 \\
\hline 2 & Polydactylus quadrifilis & $(3.2)$ & 0.199 & 1.560 & 8.225 & 0.187 & 0.142 \\
\hline 3 & Galeoides decadactylus* & (3.4) & 0.214 & 1.380 & 15.201 & 0.030 & 0.124 \\
\hline 4 & Pseudotolithus elongatus & (3.6) & 0.079 & 1.460 & 10.235 & 0.060 & 0.214 \\
\hline 5 & Pseudotolithus senegalensis* & $(3.7)$ & 0.115 & 0.687 & 5.352 & 0.010 & 0.152 \\
\hline 6 & Elops lacerta* & (3.3) & 0.854 & 2.790 & 15.450 & 1.282 & 0.101 \\
\hline 7 & Arius lastiscutatus* & $(3.3)$ & 0.160 & 0.430 & 7.290 & 0.004 & 0.126 \\
\hline 8 & Pomadasys jubelini* & (3.4) & 0.018 & 2.130 & 12.058 & 0.022 & 0.076 \\
\hline 9 & Chloroscombrus chrysurus & (3.1) & 0.117 & 2.150 & 23.817 & 0.054 & 0.159 \\
\hline 10 & Caranx hippos* & $(3.5)$ & 0.108 & 1.710 & 16.004 & 0.040 & 0.125 \\
\hline 11 & Trachinotus teraia* & $(3.3)$ & 0.119 & 0.930 & 6.885 & 0.056 & 0.364 \\
\hline 12 & Citharichthys stampflii & $(3.5)$ & 0.177 & 3.350 & 17.576 & 0.025 & 0.092 \\
\hline 13 & Cynoglossus senegalensis* & (3.4) & 0.156 & 0.510 & 6.424 & 0.025 & 0.201 \\
\hline 14 & Gerres nigri* & $(3.1)$ & 0.244 & 3.870 & 19.762 & 0.658 & 0.138 \\
\hline 15 & Drepane africana* & $(2.8)$ & 0.083 & 0.910 & 8.207 & 0.020 & 0.396 \\
\hline 16 & Dasyatis margarita* & (3.4) & 0.250 & 0.530 & 3.726 & 0.020 & 0.125 \\
\hline 17 & Ilish a africana & $(3.0)$ & 0.217 & 1.559 & 15.071 & 0.030 & 0.147 \\
\hline 18 & Brachydeuterus auritus & $(3.0)$ & 0.022 & 4.220 & 23.047 & 0.050 & 0.024 \\
\hline 19 & Hemichromis fasciatus* & (3.3) & 0.014 & 3.680 & 16.315 & 0.030 & 0.123 \\
\hline 20 & Schilbe in termedius* & $(3.0)$ & 0.009 & 4.200 & 20.980 & 0.020 & 0.180 \\
\hline 21 & Strongylura sen egalensis* & $(3.2)$ & 0.147 & 1.050 & 9.840 & 0.010 & 0.135 \\
\hline 22 & Hydrocynus forskahlii* & (3.3) & 0.027 & 1.375 & 12.310 & 0.005 & 0.245 \\
\hline 23 & Pellonula leonensis & $(3.1)$ & 0.047 & 3.560 & 26.022 & 0.070 & 0.069 \\
\hline 24 & Eleotris senegalensis* & (3.3) & 0.377 & 1.890 & 18.450 & 0.080 & 0.144 \\
\hline 25 & Chrysichthys nigrodigitatus* & (3.3) & 1.027 & 1.130 & 7.682 & 0.674 & $\mathbf{0 . 0 3 7}$ \\
\hline 26 & Trichiurus lepturus & $(3.1)$ & 0.050 & 0.600 & 5.454 & 0.001 & 0.309 \\
\hline 27 & Synodontis gambiensis * & $(2.8)$ & 0.026 & 1.600 & 12.760 & 0.010 & 0.288 \\
\hline 28 & Monodactylus sebae & (3.1) & 0.129 & 2.240 & 20.021 & 0.056 & 0.025 \\
\hline 29 & Ethmalosa fim briata & $(2.7)$ & 1.125 & 4.710 & 18.515 & 3.370 & 0.233 \\
\hline 30 & Sardinella maderensis* & $(2.9)$ & 0.550 & 4.180 & 25.229 & 0.670 & 0.105 \\
\hline 31 & Liza grandisquamis* & $(2.4)$ & 0.469 & 0.880 & 26.596 & 0.174 & 0.229 \\
\hline 32 & Tylochromis jen tinki & $(3.0)$ & 0.386 & 1.400 & 10.508 & 0.354 & 0.269 \\
\hline 33 & Sarotherodon melanotheron & $(2.1)$ & 1.456 & 1.200 & 23.820 & 0.326 & 0.066 \\
\hline 34 & Tilapia guineensis & $(2.0)$ & 0.473 & 1.440 & 34.547 & 0.151 & 0.020 \\
\hline 35 & Shrimps & $(2.6)$ & 0.910 & 3.146 & 22.000 & 0.565 & 0.322 \\
\hline 36 & Crabs & $(2.9)$ & $(4.390)$ & 2.228 & 6.285 & 1.956 & 0.310 \\
\hline 37 & Mollusks & $(2.3)$ & $(12.518)$ & 3.685 & 10.680 & - & 0.206 \\
\hline 38 & Zoobenthos & $(2.0)$ & $(4.542)$ & 3.965 & 28.000 & - & - \\
\hline 39 & Zooplankton & $(2.0)$ & 2.740 & 65.000 & 268.200 & - & 0.010 \\
\hline 40 & Phytoplankton & $(1.0)$ & 22.355 & 93.491 & - & - & - \\
\hline 41 & Phytobenthos & (1.0) & 6.480 & 83.333 & - & - & - \\
\hline 42 & Detritus & $(1.0)$ & 19.20 & - & - & - & 0.220 \\
\hline
\end{tabular}

TL: trophic level; $B$ : biomass $\left(\mathrm{tkm}^{-2}\right) ; P / B$ : annual production rate, $Q / B$ : annual consumption rate, $Y: \mathrm{catch}^{\left(\mathrm{t} k \mathrm{~km}^{-}\right.}$ $\left.{ }^{2} \mathrm{yr}^{-1}\right)$ and $O I$ : omnivory index. 
Table 2. Basic inputs and outputs (bold) of the Lake Nokoué. For fish groups with more than one species, a key species is considered and is indicated by $(*)$.

\begin{tabular}{|c|c|c|c|c|c|c|c|}
\hline & Group name & TL & $\boldsymbol{B}$ & $P / B$ & $Q / B$ & $\boldsymbol{Y}$ & $O I$ \\
\hline 1 & Polydactylus quadrifilis & 3.2 & 0.489 & 2.000 & 17.848 & 0.088 & $\mathbf{0 . 1 2 7}$ \\
\hline 2 & Elops la certa & 3.4 & 3.969 & 1.900 & 17.183 & 1.429 & 0.097 \\
\hline 3 & Pomadasys jubelini & 3.3 & 0.367 & 1.670 & 14.714 & 0.088 & 0.092 \\
\hline 4 & Caranx hippos & 3.4 & 0.030 & 2.250 & 21.487 & 0.010 & 0.054 \\
\hline 5 & Citarich thys stampflii & 3.5 & 0.070 & 2.670 & 14.477 & 0.088 & 0.082 \\
\hline 6 & Cynoglossus senegalensis* & 3.2 & 0.880 & 1.500 & 10.861 & 0.088 & 0.111 \\
\hline 7 & Eucinostomus melanopterus* & 3.2 & 1.118 & 3.560 & 26.909 & 0.840 & 0.202 \\
\hline 8 & Lutjanus goreen sis* & 3.3 & 0.326 & 1.900 & 14.397 & 0.088 & 0.081 \\
\hline 9 & Hemichromis fasciatus* & 3.3 & 0.191 & 2.560 & 18.900 & 0.088 & 0.115 \\
\hline 10 & Schilbe intermedius* & 3.1 & 0.406 & 1.800 & 25.200 & 0.292 & 0.164 \\
\hline 11 & Strongylura senegalensis* & 3.2 & 0.218 & 2.087 & 20.232 & 0.088 & 0.164 \\
\hline 12 & Hyporhamphus picarti* & 3.0 & 0.157 & 3.500 & 28.377 & 0.088 & 0.123 \\
\hline 13 & Hepsetus odoe* & 3.4 & 0.048 & 1.500 & 16.013 & 0.011 & 0.280 \\
\hline 14 & Pellonula leon ensis & 3.0 & 0.047 & 5.600 & 37.550 & 0.088 & 0.048 \\
\hline 15 & Eleotris vitatta* & 3.4 & 0.293 & 2.390 & 15.770 & 0.088 & 0.127 \\
\hline 16 & Gobionellus occidentalis* & 2.4 & 15.501 & 2.500 & 19.887 & 7.797 & 0.253 \\
\hline 17 & Chrysichthys nigrodigitatus* & 3.1 & 14.492 & 1.590 & 12.364 & 3.681 & 0.102 \\
\hline 18 & Synodontis schall* & 2.9 & 0.105 & 1.700 & 13.257 & 0.048 & 0.311 \\
\hline 19 & Monodactylus sebae & 3.2 & 0.259 & 2.700 & 21.087 & 0.088 & 0.022 \\
\hline 20 & Ethma losa fimbriata & 2.5 & 42.191 & 2.250 & 14.300 & 12.362 & 0.303 \\
\hline 21 & Liza falcipinnis* & 2.2 & 5.659 & 2.100 & 37.033 & 3.339 & 0.156 \\
\hline 22 & Sarotherodon melanotheron & 2.1 & 38.928 & 2.300 & 32.803 & 30.364 & 0.073 \\
\hline 23 & Tilapia guineensis & 2.1 & 6.673 & 2.300 & 43.800 & 3.003 & 0.124 \\
\hline 24 & Shrimps & 2.4 & 18.267 & 3.100 & 22.000 & 10.595 & 0.260 \\
\hline 25 & Crabs & 2.8 & 20.439 & 2.982 & 8.500 & 27.260 & 0.369 \\
\hline 26 & Mollusks & 2.3 & 47.227 & 3.277 & 10.680 & - & 0.233 \\
\hline 27 & Zoobenthos & 2.1 & 87.760 & 16.475 & 45.000 & - & 0.073 \\
\hline 28 & Zooplankton & 2.1 & 147.230 & 39.094 & 120.000 & - & 0.053 \\
\hline 29 & Phytoplankton & 1.0 & 29.200 & 270.000 & - & - & - \\
\hline 30 & Phytobenthos & 1.0 & 14.600 & 270.000 & - & - & - \\
\hline 31 & Detritus & 1.0 & 33.20 & - & - & - & 0.286 \\
\hline
\end{tabular}

TL: trophic level; $B$ : biomass $\left(\mathrm{tkm}^{-2}\right) ; P / B$ : annual production rate, $Q / B$ : annual consumption rate, $Y:$ catch $\left(\mathrm{tkm}^{2} \mathrm{yr}^{-1}\right)$ and $O I:$ omn ivory index. 
Table 3. Diet matrix composition (\%) of functional groups considered in the Ébrié lagoon model.

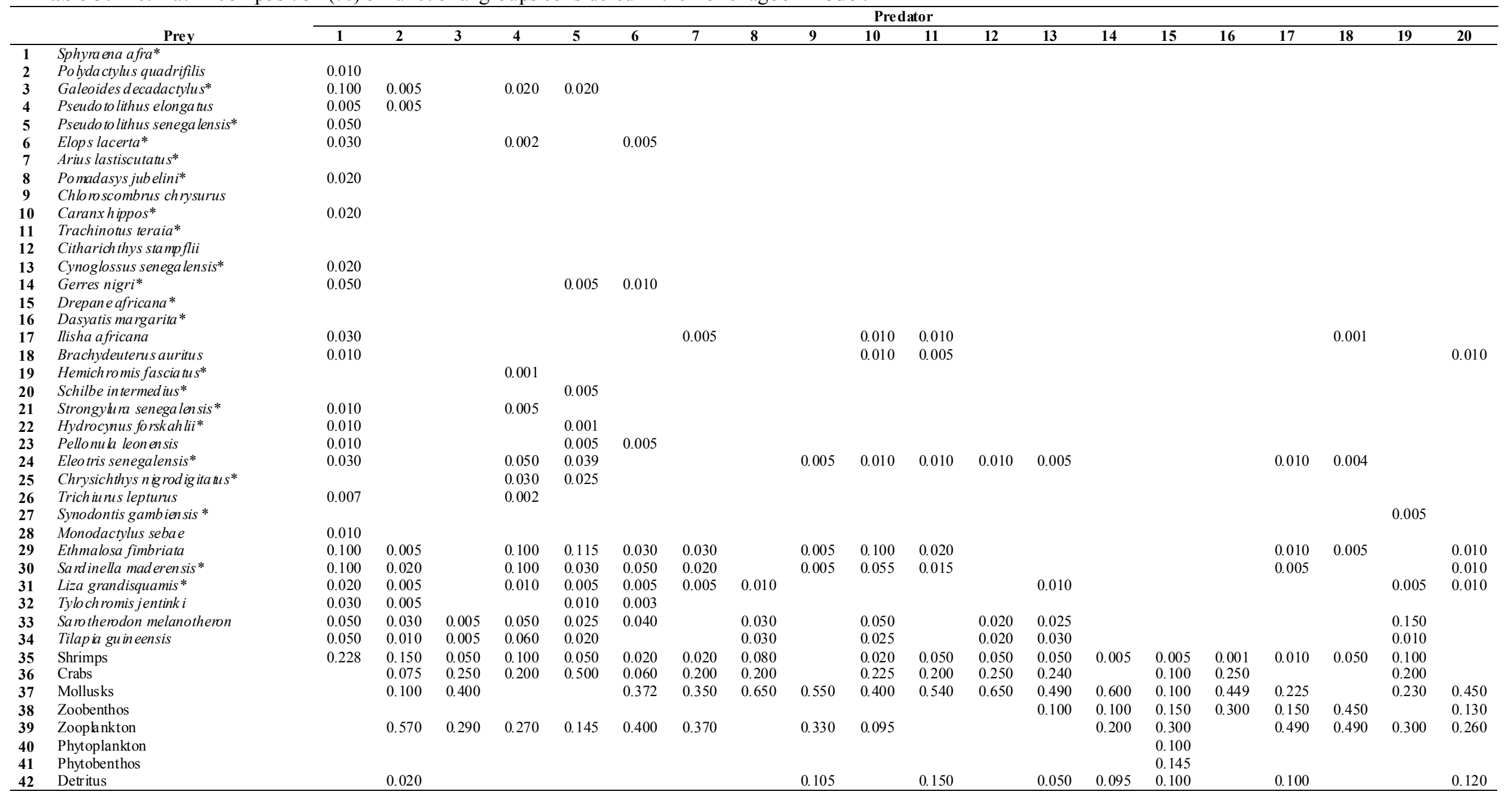


Table 3. Cont.

\begin{tabular}{|c|c|c|c|c|c|c|c|c|c|c|c|c|c|c|c|c|c|c|c|c|}
\hline & \multirow[b]{2}{*}{ Prey } & \multicolumn{19}{|c|}{ Predator } \\
\hline & & 21 & 22 & 23 & 24 & 25 & 26 & 27 & 28 & 29 & 30 & 31 & 32 & 33 & 34 & 35 & 36 & 37 & 38 & 39 \\
\hline 1 & Sphyraena afra* & & & & & & & & & & & & & & & & & & & \\
\hline 2 & Polydactylus quadrifilis & & & & & & & & & & & & & & & & & & & \\
\hline 3 & Galeoides decadactylus* & & & & & & & & & & & & & & & & & & & \\
\hline 4 & Pseudo to lithus elonga tus & & & & & & & & & & & & & & & & & & & \\
\hline 5 & Pseudo to lithus senega lensis* & & & & & & 0.002 & & & & & & & & & & & & & \\
\hline 6 & Elops lacerta* & & & & & & & & & & & & & & & & & & & \\
\hline 7 & Arius lastiscutatus* & & & & & & & & & & & & & & & & & & & \\
\hline 8 & Pomadasys jubelini* & & & & & & & & & & & & & & & & & & & \\
\hline 9 & Chloroscombrus chrysurus & & & & & & & & & & & & & & & & & & & \\
\hline 10 & Caranxhippos* & & & & & & & & & & & & & & & & & & & \\
\hline 11 & Trachinotus teraia* & & & & & & & & & & & & & & & & & & & \\
\hline 12 & Citharich thys stampflii & & & & & & & & & & & & & & & & & & & \\
\hline 13 & Cynoglossus senegalensis* & & 0.010 & & & & & & & & & & & & & & & & & \\
\hline 14 & Gerres nigri* & & & & & & & & & & & & & & & & 0.003 & & & \\
\hline 15 & Drepane africana* & & & & & & & & & & & & & & & & & & & \\
\hline 16 & Dasyatis margarita* & & & & & & & & & & & & & & & & & & & \\
\hline 17 & Ilisha a fricana & 0.050 & & & & & 0.008 & & 0.002 & & & & & & & & & & & \\
\hline 18 & Brachydeuterus auritus & & & & & & 0.010 & & 0.002 & & & & & & & & & & & \\
\hline 19 & Hemichromis fascia tus* & & & & & & & & & & & & & & & & & & & \\
\hline 20 & Schilbe in termed ius* & & & & & & & & & & & & & & & & & & & \\
\hline 21 & Strongyhura senegalensis* & & 0.030 & & & & & & & & & & & & & & & & & \\
\hline 22 & Hydrocynus foskah lii* & & 0.030 & & & & & & & & & & & & & & & & & \\
\hline 23 & Pellonula leonensis & & & & & & & & & & & & & & & & & & & \\
\hline 24 & Eleotris senegalensis* & 0.020 & 0.005 & & & & & & & & & & & & & & & & & \\
\hline 25 & Chrysichthys nigrodigita tus* & & 0.010 & & & & & & & & & & & & & & & & & \\
\hline 26 & Trichiunus lepturus & & 0.001 & & & & & & & & & & & & & & & & & \\
\hline 27 & Synodontis gambiensis* & & 0.001 & & & & & & & & & & & & & & & & & \\
\hline 28 & Monodactylus sebae & & & & & & & & & & & & & & & & & & & \\
\hline 29 & Ethmalosa fimbriata & 0.100 & 0.020 & 0.050 & 0.050 & 0.004 & 0.050 & & 0.005 & & & & & & & & 0.015 & & & \\
\hline 30 & Sandinella maderensis* & 0.050 & & 0.050 & 0.020 & & 0.050 & & 0.005 & & & & & & & & 0.010 & & & \\
\hline 31 & Liza grandisquamis* & 0.005 & 0.010 & & & & 0.005 & & 0.005 & & & & & & & & 0.001 & & & \\
\hline 32 & Tylochromis jentink $i$ & 0.005 & 0.005 & & 0.005 & & & & & & & & 0.006 & & & & & & & \\
\hline 33 & Sarotherodon melanotheron & 0.050 & 0.005 & & 0.010 & 0.005 & 0.020 & & & & & & 0.006 & & & & & & & \\
\hline 34 & Tilapia guineensis & 0.020 & 0.003 & 0.010 & 0.010 & 0.001 & 0.004 & & & & & & 0.006 & & & & & & & \\
\hline 35 & Shrimps & & 0.020 & 0.050 & 0.005 & 0.005 & 0.010 & & 0.030 & & 0.010 & & 0.010 & & & & & & & \\
\hline 36 & Crabs & & 0.100 & & 0.190 & 0.045 & 0.100 & & & & & & & & & & 0.026 & & & \\
\hline 37 & Mollusks & & 0.300 & 0.050 & 0.160 & 0.710 & 0.121 & 0.350 & 0.105 & 0.010 & 0.080 & & 0.600 & & & 0.200 & 0.450 & & & \\
\hline 38 & Zoobenthos & 0.300 & 0.200 & 0.090 & 0.370 & & & 0.350 & 0.300 & 0.010 & 0.060 & 0.200 & 0.159 & & & & 0.259 & & & \\
\hline 39 & Zooplankton & 0.400 & 0.200 & 0.700 & 0.180 & 0.230 & 0.490 & & 0.546 & 0.635 & 0.750 & 0.150 & & 0.070 & 0.020 & 0.300 & & 0.280 & & 0.010 \\
\hline 40 & Phytoplankton & & & & & & & 0.150 & & 0.325 & & 0.200 & 0.100 & 0.280 & 0.180 & 0.300 & & 0.300 & & 0.850 \\
\hline 41 & Phytobenthos & & & & & & & 0.050 & & 0.010 & & 0.150 & & 0.050 & 0.200 & & 0.031 & 0.150 & 0.150 & \\
\hline 42 & Detritus & & 0.050 & & & & 0.130 & 0.100 & & 0.010 & 0.100 & 0.300 & 0.114 & 0.600 & 0.600 & 0.200 & 0.205 & 0.270 & 0.850 & 0.140 \\
\hline
\end{tabular}


Table 4. Diet matrix composition (\%) of groups considered in Lake Nokoué model.

Pre dator

\begin{tabular}{|c|c|c|c|c|c|c|c|c|c|c|c|c|c|c|c|c|c|c|c|c|c|c|c|c|c|c|c|c|c|}
\hline & Prey & 1 & 2 & 3 & 4 & 5 & 6 & 7 & 8 & 9 & 10 & 11 & 12 & 13 & 14 & 15 & 16 & 17 & 18 & 19 & 20 & 21 & 22 & 23 & 24 & 25 & 26 & 27 & 28 \\
\hline 1 & Polydactylus quadrifilis & & & & & & & & & & & & & & & & & & & & & & & & & & & & \\
\hline 2 & Elops lacerta & & 0.020 & & & & & 0.005 & & 0.010 & & & & & & & & & & & & & & & & & & & \\
\hline 3 & Pomadasys jubelini & & & & & & & & & & & & & & & & & & & & & & & & & & & & \\
\hline 4 & Caranx hippos & & & & & & & & & & & & & & & & & & & & & & & & & & & & \\
\hline 5 & Citharichthys stampflii & & & & & & & & & & & & & & & & & & & & & & & & & & & & \\
\hline 6 & Cynoglossus senegalensis* & & & & & & & & & & & & & & & & & & & & & & & & & & & & \\
\hline 7 & $\begin{array}{l}\text { Eucinostomus } \\
\text { melanopterus* }\end{array}$ & & 0.010 & & & & & & & & & & & & & & & & & & & & & & & 0.003 & & & \\
\hline 8 & Lutjanus goreen sis* & & 0.002 & & & 0.025 & & & & & & & & & & & & & & & & & & & & & & & \\
\hline 9 & Hemichromis fasciatus* & & & & & & & & & 0.005 & & & & & & & & & & & & & & & & & & & \\
\hline 10 & Schilbe intermedius* & & & & & & & & & & & & & 0.100 & & & & & & & & & & & & & & & \\
\hline 11 & Strongylura senegalensis* & & & & & & & & & & & 0.003 & & & & & & & & & & & & & & & & & \\
\hline 12 & Hyporhamphus picarti* & & & & & & & & & & & 0.010 & & & & & & & & & & & & & & & & & \\
\hline 13 & Hepsetus odoe* & & & & & & & & & 0.005 & & & & 0.005 & & & & & & & & & & & & & & & \\
\hline 14 & Pellonula leonensis & & 0.001 & 0.001 & & 0.005 & 0.001 & & 0.005 & 0.005 & & 0.002 & & 0.005 & & 0.005 & & & & & & & & & & & & & \\
\hline 15 & Eleotris vitatta* & & & 0.020 & & & & & & & 0.010 & & & & & & & & & & & & & & & & & & \\
\hline 16 & Gobionellus occidentalis* & & 0.150 & 0.030 & & 0.070 & & 0.050 & 0.050 & 0.050 & 0.050 & 0.050 & & 0.070 & & & & & & & & & & & & & & & \\
\hline 17 & Chrysichthys nigrodigitatus* & & & & & & & & 0.065 & 0.050 & & 0.030 & & 0.100 & & 0.050 & & & & & & & & & & & & & \\
\hline 18 & Synodontis schall* & & & & & & & & & & 0.005 & & & 0.080 & & & & & & & & & & & & & & & \\
\hline 19 & Monodactylus sebae & & & & & & & & & & & & & & & & & & & & & & & & & & & & \\
\hline 20 & Ethma losa fimbriata & 0.050 & 0.100 & 0.050 & 0.050 & 0.050 & 0.050 & 0.250 & 0.150 & 0.150 & 0.055 & 0.045 & & 0.050 & & 0.020 & & & & & 0.020 & & & & & 0.025 & & & \\
\hline 21 & Liza falcipinnis* & & 0.050 & 0.040 & 0.050 & 0.030 & & 0.060 & & 0.020 & & & & & & 0.005 & & & & & & & & & & & & & \\
\hline 22 & Sarotherodon melanotheron & 0.100 & 0.100 & 0.055 & 0.050 & 0.030 & 0.050 & 0.100 & & 0.100 & 0.100 & 0.070 & & 0.210 & & 0.010 & & 0.005 & & & 0.015 & & & & & & & & \\
\hline 23 & Tilapia guineensis & 0.050 & 0.050 & 0.014 & 0.050 & 0.010 & & 0.035 & & 0.100 & 0.030 & 0.040 & & 0.200 & & 0.030 & & 0.005 & & & & & & & & & & & \\
\hline 24 & Shrimps & 0.100 & 0.150 & 0.400 & 0.400 & 0.400 & 0.200 & 0.050 & 0.250 & 0.100 & 0.050 & 0.150 & & & 0.010 & 0.290 & 0.005 & 0.050 & & 0.300 & 0.010 & & & 0.005 & & & & & \\
\hline 25 & Crabs & 0.100 & 0.170 & 0.100 & 0.150 & 0.250 & 0.050 & 0.050 & & 0.050 & 0.010 & 0.100 & & & & 0.200 & & 0.050 & & & & & & & & 0.027 & & & \\
\hline 26 & Mollusks & 0.050 & 0.007 & 0.010 & 0.100 & 0.010 & 0.150 & 0.200 & 0.050 & 0.150 & 0.300 & 0.100 & 0.200 & & 0.050 & 0.200 & & 0.300 & 0.400 & 0.200 & 0.020 & 0.010 & & 0.010 & & 0.300 & & & \\
\hline 27 & Zoobenthos & 0.150 & 0.030 & 0.020 & 0.050 & 0.020 & 0.250 & 0.030 & 0.230 & 0.150 & 0.200 & 0.200 & 0.500 & 0.100 & 0.150 & 0.070 & 0.175 & 0.450 & 0.210 & 0.100 & 0.050 & 0.050 & 0.020 & 0.050 & 0.250 & 0.300 & & 0.020 & \\
\hline 28 & Zooplankton & 0.350 & 0.160 & 0.250 & 0.100 & 0.100 & 0.200 & 0.070 & 0.200 & 0.045 & 0.100 & 0.150 & 0.200 & 0.030 & 0.750 & 0.100 & 0.150 & 0.090 & 0.100 & 0.400 & 0.350 & 0.100 & 0.050 & 0.050 & 0.100 & & 0.300 & 0.050 & 0.050 \\
\hline 29 & Phytoplankton & & & & & & & & & & & & & & 0.040 & & 0.100 & & & & 0.250 & 0.150 & 0.150 & 0.300 & 0.010 & & 0.150 & 0.010 & 0.100 \\
\hline 30 & Phytobenthos & & & & & & & 0.050 & & 0.010 & 0.015 & 0.050 & 0.050 & & & & 0.150 & & 0.100 & & 0.050 & 0.250 & 0.150 & 0.300 & 0.040 & 0.030 & 0.050 & 0.100 & 0.050 \\
\hline 31 & Detritus & 0.050 & & 0.010 & & & 0.049 & 0.050 & & & 0.075 & & 0.050 & 0.050 & & 0.020 & 0.420 & 0.050 & 0.190 & & 0.235 & 0.440 & 0.630 & 0.285 & 0.600 & 0.315 & 0.500 & 0.820 & 0.800 \\
\hline
\end{tabular}


Table 5. Relative distribution of biomass $\left(\mathrm{tkm}^{-2}\right)$ and catch $\left(\mathrm{tkm}^{-2} \mathrm{yr}^{-1}\right)$ among the various TLs in Ébrié Lagoon (E) and in Lake Nokoué (N). Note that biomass and/or catch of non-fish groups are not included.

\begin{tabular}{|c|c|c|c|c|c|c|c|c|}
\hline \multirow[t]{2}{*}{ TL } & \multicolumn{2}{|c|}{ Biomass } & \multicolumn{2}{|c|}{ Contribution per TL (\%) } & \multicolumn{2}{|c|}{ Catch } & \multicolumn{2}{|c|}{ Contribution per TL (\%) } \\
\hline & $\mathbf{E}$ & $\mathbf{N}$ & $\mathbf{E}$ & $\mathbf{N}$ & $\mathbf{E}$ & $\mathbf{N}$ & $\mathbf{E}$ & $\mathbf{N}$ \\
\hline $\mathrm{V}$ & 0.112 & 0.296 & 1.2 & 0.2 & 0.051 & 0.106 & 0.6 & - \\
\hline IV & 1.260 & 5.230 & 13.3 & 4.0 & 0.871 & 1.746 & 10.1 & 2.7 \\
\hline II & 2.700 & 82.000 & 28.5 & 62.0 & 2.000 & 46.200 & 23.3 & 72.0 \\
\hline
\end{tabular}


Table 6. Summary statistics and network flow indices of the two ecosystems considered.

\begin{tabular}{|c|c|c|}
\hline \multirow{2}{*}{ Parameter } & \multicolumn{2}{|c|}{ Value } \\
\hline & Ébrié & Nokoué \\
\hline \multicolumn{3}{|l|}{ Ecosystem theory indices } \\
\hline Sum of all consumption $\left(\mathrm{tkm}^{-2} \mathrm{yr}^{-1}\right)$ & 1207.682 & 25731.420 \\
\hline Sum of all exports $\left(\mathrm{tkm}^{-2} \mathrm{yr}^{-1}\right)$ & 2119.768 & 1327.479 \\
\hline Sum of all respiratory flows $\left(\mathrm{tkm}^{-2} \mathrm{yr}^{-1}\right)$ & 510.942 & 10498.570 \\
\hline Sum of all flows into detritus $\left(\mathrm{tkm}^{-2} \mathrm{yr}^{-1}\right)$ & 2402.998 & 20410.000 \\
\hline 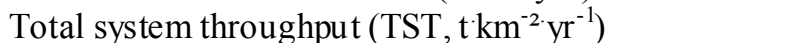 & 6240.000 & 57967.000 \\
\hline Sum of all production $\left(\mathrm{tkm}^{2} \mathrm{yr}^{-1}\right)$ & 2902.000 & 19595.000 \\
\hline Mean trophic level of the catch & 2.88 & 2.46 \\
\hline Gross efficiency (GE, catch/net p.p.) & 0.004226 & 0.008625 \\
\hline Calculated total net primary production $\left(\mathrm{t} \mathrm{km}^{-2} \mathrm{yr}^{-1}\right)$ & 2629.989 & 11826.000 \\
\hline Total primary production/total respiration (TPP/TR) & 5.155 & 1.126 \\
\hline Net system production (PP-TR, $\left.\mathrm{t}^{\mathrm{km}}{ }^{-2} \mathrm{yr}^{-1}\right)$ & 2119.047 & 1327.430 \\
\hline Total primary production/total biomass $\left(\mathrm{PP} / B, \mathrm{yr}^{-1}\right)$ & 41.596 & 23.788 \\
\hline Total biomass/total system throughput ( $B$-TST, $\left.\mathrm{yr}^{-1}\right)$ & 0.010 & 0.009 \\
\hline Total biomass (excluding detritus) $\left(\mathrm{t} \mathrm{km}^{-2}\right)$ & 63.304 & 497.141 \\
\hline Total catches $\left(\mathrm{tkm}^{-2} \mathrm{yr}^{-1}\right)$ & 11.115 & 101.999 \\
\hline Connectance Index $(C I)$ & 0.191 & 0.266 \\
\hline System Omnivory Index $(\mathrm{SOI})$ & 0.145 & 0.156 \\
\hline \multicolumn{3}{|l|}{ Cycling indices } \\
\hline Throughput cycled excluding detritus $\left(\mathrm{t}^{\mathrm{km}}{ }^{-2} \mathrm{yr}^{-1}\right)$ & 8.16 & 980.57 \\
\hline Throughput cycled (including detritus) $\left(\mathrm{tkm}^{-2} \mathrm{yr}^{-1}\right)$ & 5.09 & 4.98 \\
\hline Finn's cycling index (FCI, \%) & 2.57 & 34.00 \\
\hline Predato ry cycling index (PCI, \%) & 0.57 & 5.72 \\
\hline Finn's mean path length & 2.373 & 4.902 \\
\hline Finn's straight-through path length (excluding detritus) & 2.733 & 1.525 \\
\hline Finn's straight-through path length (including detritus) & 2.312 & 3.235 \\
\hline \multicolumn{3}{|l|}{ Information indices } \\
\hline Ascendancy ( $A$, flowbits) & 7656.10 & 47224.00 \\
\hline Overhead ( $\varnothing$, flowbits) & 13876.70 & 186154.30 \\
\hline Capacity $(C$, flowbits) & 21032.90 & 233378.30 \\
\hline In formation $(I)$ & 1.147 & 0.815 \\
\hline$A / C$ & 0.340 & 0.202 \\
\hline
\end{tabular}

